\title{
Concerted measurements of free amino acids at the Cabo Verde islands: high enrichments in submicron sea spray aerosol particles and cloud droplets
}

\author{
Nadja Triesch ${ }^{1}$, Manuela van Pinxteren ${ }^{1}$, Anja Engel ${ }^{2}$, and Hartmut Herrmann ${ }^{1}$ \\ ${ }^{1}$ Atmospheric Chemistry Department (ACD), Leibniz-Institute for Tropospheric Research (TROPOS), \\ Leipzig 04318, Germany \\ ${ }^{2}$ GEOMAR Helmholtz Centre for Ocean Research, Kiel 24105, Germany
}

Correspondence: Hartmut Herrmann (herrmann@tropos.de)

Received: 23 October 2019 - Discussion started: 17 February 2020

Revised: 5 November 2020 - Accepted: 13 November 2020 - Published: 11 January 2021

\begin{abstract}
Measurements of free amino acids (FAAs) in the marine environment to elucidate their transfer from the ocean into the atmosphere, to marine aerosol particles and to clouds, were performed at the MarParCloud (marine biological production, organic aerosol particles and marine clouds: a process chain) campaign at the Cabo Verde islands in autumn 2017. According to physical and chemical specifications such as the behavior of air masses, particulate MSA concentrations and MSA/sulfate ratios, as well as particulate mass concentrations of dust tracers, aerosol particles predominantly of marine origin with low to medium dust influences were observed. FAAs were investigated in different compartments: they were examined in two types of seawater underlying water (ULW) and in the sea surface microlayer (SML), as well as in ambient marine size-segregated aerosol particle samples at two heights (ground height based at the Cape Verde Atmospheric Observatory, CVAO, and at $744 \mathrm{~m}$ height on Mt. Verde) and in cloud water using concerted measurements. The $\sum$ FAA concentration in the SML varied between 0.13 and $3.64 \mu \mathrm{mol} \mathrm{L}{ }^{-1}$, whereas it was between 0.01 and $1.10 \mu \mathrm{mol} \mathrm{L}^{-1}$ in the ULW; also, a strong enrichment of $\sum$ FAA (EF SML $_{\text {: }}$ 1.1-298.4, average of 57.2) was found in the SML. In the submicron $(0.05-1.2 \mu \mathrm{m})$ aerosol particles at the CVAO, the composition of FAAs was more complex, and higher atmospheric concentrations of $\sum F A A$ (up to $6.3 \mathrm{ng} \mathrm{m}^{-3}$ ) compared to the supermicron $(1.2-10 \mu \mathrm{m}$ ) aerosol particles (maximum of $0.5 \mathrm{ng} \mathrm{m}^{-3}$ ) were observed. The total $\sum$ FAA concentration $\left(\mathrm{PM}_{10}\right)$ was between 1.8 and $6.8 \mathrm{ng} \mathrm{m}^{-3}$ and tended to increase during the campaign.
\end{abstract}

Averaged $\sum$ FAA concentrations in the aerosol particles on Mt. Verde were lower (submicron: $1.5 \mathrm{ng} \mathrm{m}^{-3}$; supermicron: $1.2 \mathrm{ng} \mathrm{m}^{-3}$ ) compared to the CVAO. A similar contribution percentage of $\sum$ FAA to dissolved organic carbon (DOC) in the seawater (up to $7.6 \%$ ) and to water-soluble organic carbon (WSOC) in the submicron aerosol particles (up to $5.3 \%$ ) indicated a related transfer process of FAAs and DOC in the marine environment.

Considering solely ocean-atmosphere transfer and neglecting atmospheric processing, high FAA enrichment factors were found in both aerosol particles in the submicron range $\left(\mathrm{EF}_{\mathrm{aer}\left(\sum \mathrm{FAA}\right)}: 2 \times 10^{3}-6 \times 10^{3}\right)$ and medium enrichment factors in the supermicron range $\left(\mathrm{EF}_{\text {aer }}\left(\sum \mathrm{FAA}\right): 1 \times 10^{1}-\right.$ $\left.3 \times 10^{1}\right)$. In addition, indications for a biogenic FAA formation were observed. Furthermore, one striking finding was the high and varying FAA cloud water concentration (11.2$\left.489.9 \mathrm{ng} \mathrm{m}^{-3}\right)$, as well as enrichments $\left(\mathrm{EF}_{\mathrm{CW}}: 4 \times 10^{3}\right.$ and $1 \times 10^{4}$ compared to the SML and ULW, respectively), which were reported here for the first time. The abundance of inorganic marine tracers (sodium, methanesulfonic acid) in cloud water suggests an influence of oceanic sources on marine clouds. Finally, the varying composition of the FAAs in the different matrices shows that their abundance and oceanatmosphere transfer are influenced by additional biotic and abiotic formation and degradation processes. Simple physicochemical parameters (e.g., surface activity) are not sufficient to describe the concentration and enrichments of the FAAs in the marine environment. For a precise representation in organic matter $(\mathrm{OM})$ transfer models, further studies 
are needed to unravel their drivers and understand their composition.

\section{Introduction}

Amino acids contribute to the global nitrogen and carbon cycle and to the atmosphere-biosphere nutrient cycle (Zhang and Anastasio, 2003; Wedyan and Preston, 2008). They can be divided into free single amino acids (FAAs) and combined amino acids (CAAs), which include proteins, peptides and other combined forms (Mandalakis et al., 2011). Amino acids are produced in the ocean and are reported to be in the upper layer of the ocean, the sea surface microlayer (SML) (Kuznetsova et al., 2004; Reinthaler et al., 2008; van Pinxteren et al., 2012; Engel and Galgani, 2016). The SML, as the direct interface between the ocean and the atmosphere, may play an important role as a source of organic matter (OM) in aerosol particles within the marine environment (Cunliffe et al., 2013; Engel et al., 2017; Wurl et al., 2017). Specific organic groups of compounds, including nitrogenous OM (Engel and Galgani, 2016), can be strongly enriched in the SML. From the ocean, amino acids, as part of the class of proteinaceous compounds, can be transferred into atmospheric particles via bubble bursting (Kuznetsova et al., 2005; Rastelli et al., 2017). These proteinaceous compounds are often analyzed as sum parameter "proteins" using an analytical staining method with Coomassie blue developed by Bradford (1976) and have often been applied in previous studies (Gutiérrez-Castillo et al., 2005; Mandalakis et al., 2011; Rastelli et al., 2017). Despite their attribution to proteins, the FAAs are better utilizable forms of nitrogen instead of proteins for aquatic organisms such as phytoplankton and bacteria (Antia et al., 1991; McGregor and Anastasio, 2001).

Due to their structure and hygroscopic properties, amino acids can act as both ice-forming particles (INPs) (Wolber and Warren, 1989; Szyrmer and Zawadzki, 1997; Pandey et al., 2016; Kanji et al., 2017) and cloud condensation nuclei (CCN) (Kristensson et al., 2010) in the atmosphere, while amino acids such as arginine and asparagine can exist as metastable droplets instead of solid particles at low relative humidity; this has been shown a laboratory study (Chan et al., 2005). In general, previous studies have shown that amino acids in aerosol particles can have both natural and anthropogenic sources. Having been detected in volcanic emissions (Scalabrin et al., 2012) and during biomass burning events (Chan et al., 2005; Feltracco et al., 2019), amino acids can be produced by plants, pollens, fungi, bacterial spores and algae (Milne and Zika, 1993; Zhang and Anastasio, 2003; Matos et al., 2016). Nevertheless, they are useful indicators for aerosol particle age and origin (Barbaro et al., 2011; Matsumoto and Uematsu, 2005; Scalabrin et al., 2012). Based on a cluster and factor analysis, Scalabrin et al. (2012) suggested two possible sources for the amino acids in the ultrafine Arctic aerosol particles. The authors first mentioned the regional development (isoleucine, leucine, threonine) and long-range transport (glycine) of amino acids from marine areas and secondly, the influence of local sources such as of marine primary production (proline, valine, serine, tyrosine, glutamic acid). A different approach by Mashayekhy Rad et al. (2019) investigated the atmospheric proteinogenic aerosol particles in the Arctic and attributed them to different sources based, among others, on the reactivity of the distinct amino acids. The authors differentiated here between long-range transport (glycine), terrestrial and marine aerosol particles (proline, valine, serine, tyrosine), and coastal and marine phytoplankton and bacteria (isoleucine, leucine and threonine) as important sources for amino acids (Mashayekhy Rad et al., 2019). In fact, previous studies have assigned individual amino acids to specific marine biogenic sources and used them as biomarkers. Hammer and Kattner (1986) reported correlations between aspartic acid, diatoms and zooplankton in seawater. GABA ( $\gamma$-aminobutyric acid) was referred to as an indicator for the microbiological decomposition of OM (Dauwe et al., 1999; Engel et al., 2018) and is used as a microbiological proxy in aerosol particles. To facilitate the comparison of amino acids in different studies, one possibility is to group them according to the physiochemical properties of amino acids ("hydropathy index"; Kyte and Doolittle, 1982), as Pommié et al. (2004) suggested based on the partition coefficient between water and ethanol. This divides them into hydrophilic, neutral and hydrophobic amino acids as discussed in Barbaro et al. (2015), for FAAs in Antarctic aerosol particles. They also observed that hydrophilic FAAs in the Antarctic were predominant in locally produced marine aerosol particles, while hydrophobic amino acids prevailed in aerosol particles collected at the continental station.

Although the study and characterization of amino acids are of paramount importance for atmospheric scientists, the true role and the fate of amino acids in the atmosphere are still poorly understood (Matos et al., 2016). Despite several studies of FAAs also conducted in the marine environment, there is still a huge uncertainty as to the question of whether FAAs are of marine origin or not. Matsumoto and Uematsu (2005) showed that the long-range transport of land-derived sources largely contributes to the amino acid concentration in the North Pacific. On the other hand, based on a positive correlation between amino acids in seawater and the atmosphere, Wedyan and Preston (2008) pointed out that the particulate amino acids in the Southern Ocean are of marine origin. These findings are likely due to regionally varying source strengths, given different meteorological and biological conditions, which necessarily require further measurements in distinct marine regions. Unfortunately, measurements are lacking that regard the abundance and molecular composition of amino acids in both seawater and sizesegregated aerosol particles, especially in the tropical Atlantic Ocean. 
So the aim of the present study is to investigate the occurrence of FAAs in the marine environment which includes all important compartments: i.e., the seawater underlying water (ULW), the SML, the aerosol particles and finally cloud water in the remote tropical North Atlantic Ocean at the Cape Verde Atmospheric Observatory (CVAO). Their abundance, origin and possible transfer from the seawater, as well as their transport within the atmosphere, are studied in particular. Therefore, the FAAs are measured on a molecular level and divided into hydrophilic (glutamic acid, aspartic acid, GABA), neutral (serine, glycine, threonine, proline, tyrosine) and hydrophobic (alanine, valine, phenylalanine, isoleucine, leucine) compounds according to their hydropathy index. The similarities and differences between the amino acid composition in submicron $(0.05-1.2 \mu \mathrm{m})$ and supermicron (1.2$10 \mu \mathrm{m})$ aerosol particles are especially elucidated. Finally, the potential of individual FAAs as proxies or tracers for specific sources of aerosol particles and cloud water in the tropical marine environment is outlined.

\section{Experiment}

\subsection{Study area}

Within the framework of the MarParCloud (marine biological production, organic aerosol particles and marine clouds: a process chain) project with contributions from MARSU (MARine atmospheric Science Unravelled: analytical and mass spectrometric techniques development and application), a field campaign was performed at the CVAO from 13 September to 13 October 2017. This remote marine station is located on the northeast coast of the island of São Vicente, directly by the ocean $\left(16^{\circ} 51^{\prime} 49^{\prime \prime} \mathrm{N}, 24^{\circ} 52^{\prime} 02^{\prime \prime} \mathrm{E}\right)$, which Carpenter et al. (2010) and Fomba et al. (2014) described in more detail. In accordance with the classification of Longhurst (2007), the ocean around the Cabo Verde islands belongs to the region "North Atlantic Tropical Gyral Province" (NATR), which is described as the region with the lowest surface chlorophyll in the North Atlantic Ocean that has a greater annual than seasonal variability. During this campaign, concerted measurements were performed including the sampling of size-segregated aerosol particles at the CVAO and seawater sampling at the ocean site ( $\left.\sim 16^{\circ} 53^{\prime} 17^{\prime \prime} \mathrm{N}, \sim 24^{\circ} 54^{\prime} 25^{\prime \prime} \mathrm{E}\right)$. The location was carefully chosen to have a minimal influence from the island and was located in the wind direction of the CVAO as shown in Fig. S1. Here, an aerosol particle sampler and cloud water sampler were installed at the mountain station "Monte Verde" (MV) on the top of the mountain $\left(16^{\circ} 52^{\prime} 11^{\prime \prime} \mathrm{N}\right.$, $\left.24^{\circ} 56^{\prime} 02^{\prime \prime} \mathrm{W}\right)$. Further details on the MarParCloud campaign are provided by van Pinxteren et al. (2020).

\subsubsection{Seawater sampling}

The seawater samples were taken from a fishing boat, launching from Baía das Gatas, São Vicente. A glass plate with a sampling area of $2500 \mathrm{~cm}^{2}$ was vertically immersed in the seawater and then slowly drawn upwards to take the SML. The surface films adhered to the surface of the glass plate and were removed with Teflon wipers directly into a bottle. This glass plate approach is described in detail by Cunliffe (2014). The ULW was sampled at a depth of $1 \mathrm{~m}$ into a plastic bottle fitted on a telescopic rod. To avoid influences from the SML, the bottles were opened underwater at the intended sampling depth. All seawater samples were stored in plastic bottles at $-20^{\circ} \mathrm{C}$ until the time of analysis. All materials for the seawater sampling were pre-cleaned with a $10 \% \mathrm{HCl}$ solution and high-purity water.

\subsubsection{Aerosol particle sampling}

Size-segregated aerosol particles were sampled using fivestage Berner-type impactors (Hauke, Gmunden, Austria) at the top of a $30 \mathrm{~m}$ sampling tower at the CVAO since this location best represents the conditions above the ocean in accordance with previous studies. The internal boundary layer (IBL), which can form when air passes a surface with changing roughness (i.e., the transfer from open water to island), is mainly beneath $30 \mathrm{~m}$ (Niedermeier et al., 2014). Moreover, aerosol particles were sampled on the top of MV (744 $\mathrm{m}$ a.s.1.). To avoid the condensation of atmospheric water in the aerosol particle sampling substrate, a conditioning unit consisting of a $3 \mathrm{~m}$ long tube was installed between the impactor inlet and the sampling unit. By heating the sampled air, the high relative humidity of the ambient air before collecting the aerosol particles was set to $75 \%-80 \%$. The temperature difference between the ambient air at the impactor inlet and the sampled air after the conditioning unit was below 9 K (van Pinxteren et al., 2020). The Berner impactors were operated with a flow rate of $75 \mathrm{~L} \mathrm{~min}^{-1}$ for $24 \mathrm{~h}$, and pre-baked aluminum foils $\left(350^{\circ} \mathrm{C}\right.$ for $\left.2 \mathrm{~h}\right)$ were used as substrate material. The five stage Berner impactor includes stage 1 (B1): $0.05-0.14 \mu \mathrm{m}$; stage 2 (B2): 0.14-0.42 $\mu \mathrm{m}$; stage 3 (B3): $0.42-1.2 \mu \mathrm{m}$; stage 4 (B4): $1.2-3.5 \mu \mathrm{m}$ and stage 5 (B5): $3.5-10 \mu \mathrm{m}$. When it comes to the segregated aerosol particle samples, our study differentiates between the ones of submicron size (B1, B2, B3), the ones of supermicron size (B4, B5) and the ones of $\mathrm{PM}_{10}$ (B1-5). After the sampling, the aluminum foils were stored in aluminum boxes at $-20^{\circ} \mathrm{C}$ until the time of analysis. It needs to be pointed out that the Berner impactors ran continuously; thus, the impactor on MV sampled aerosol particles also during cloud events. However, due to the preconditioning unit, the cloud droplets were efficiently removed before the aerosol particles were collected on the aluminum foils. 


\subsubsection{Cloud water sampling}

At the MV station, an acrylic glass Caltech Active Strand Cloud water Collector version 2 (CASCC2), according to Demoz et al. (1996), was used to sample cloud water. During a "cloud event", the bottles were changed every $2-3 \mathrm{~h}$, whereas on the other days, the sampling time was, e.g., overnight (every $12 \mathrm{~h}$ ). For each sampling, the Teflon rods used were pre-cleaned with a $10 \% \mathrm{HCl}$ solution followed by high-purity water. The liquid water content (LWC) of the cloud was measured continuously by a particle volume monitor (PVM-100, Gerber Scientific, USA). Finally, the collected cloud water was sampled in pre-cleaned plastic bottles and stored at $-20^{\circ} \mathrm{C}$ until the time of analysis.

\subsection{Analyses}

\subsubsection{Seawater analyses}

For the dissolved organic carbon and total dissolved nitrogen (DOC/TDN) content and the analysis of inorganic ions, the seawater samples were first filtered $(0.45 \mu \mathrm{m}$ syringe filter) and then quantified with a TOC-VCPH analyzer (Shimadzu, Japan) or ion chromatography (ICS3000, Dionex, Sunnyvale, CA, USA), as described in van Pinxteren et al. (2017). As the seawater samples must first undergo a desalination step for the FAA analysis, $32 \mathrm{~mL}$ (SML samples) or $48 \mathrm{~mL}$ (ULW samples) were desalinated using Dionex ${ }^{\mathrm{TM}}$ OnGuard $^{\mathrm{TM}}$ II $\mathrm{Ag} / \mathrm{H}$ cartridges (Thermo Fisher Scientific ${ }^{\mathrm{TM}}$, Waltham, Massachusetts, USA). The volume of the desalinated samples was reduced to several microliters using a vacuum concentrator at $T=30^{\circ} \mathrm{C}$ (miVac sample Duo, GeneVac Ltd., Ipswich, United Kingdom) with a recovery rate of $>86 \%$. The $0.2 \mu \mathrm{m}$ syringe filters (Acrodisc GHP, $25 \mathrm{~mm}$; Pall Corporation, New York, USA) enabled the filtering of the enriched samples; then, a derivatization was performed with the AccQ-TagTM precolumn derivatization method (Waters, Eschborn, Germany). Besides, the FAA analysis includes the determination of glycine (Gly), L-alanine (Ala), L-serine (Ser), Lglutamic acid (Glu), L-threonine (Thr), L-proline (Pro), Ltyrosine (Tyr), L-valine (Val), L-phenylalanine (Phe), Laspartic acid (Asp), L-isoleucine (Ile), L-leucine (Leu), Lmethionine (Met), L-glutamine (Gln) and $\gamma$-aminobutyric acid (GABA) (purity $\geq 99 \%$; Sigma-Aldrich, St. Louis, Missouri, USA). Ultra-high performance liquid chromatography with electrospray ionization and Orbitrap mass spectrometry (UHPLC/ESI-Orbitrap-MS) performed the analytical measurements of the derivatized FAAs. The UHPLC system (Vanquish Horizon UHPLC system, Thermo Fisher Scientific ${ }^{\mathrm{TM}}$, Waltham, Massachusetts, USA) was coupled with an ESI-Orbitrap mass spectrometer (Q Exactive ${ }^{\mathrm{TM}}$ plus, Thermo Fisher Scientific ${ }^{\mathrm{TM}}$, Waltham, Massachusetts, USA). The samples were subsequently separated through an ACQUITY UPLC ${ }^{\circledR}$ HSS T3 column (Waters, Eschborn, Ger- many) with dimensions of $1.8 \mu \mathrm{m}$ (particle size), $2.1 \mathrm{~mm}$ (inner diameter) and $100 \mathrm{~mm}$ (length) at a constant temperature of $30^{\circ} \mathrm{C}$ and a detection in positive mode. The eluent composition consisted of (A) $0.2 \mathrm{vol} \%$ acetic acid in high-purity water (Millipore Elix 3 and Element A10, Merck Millipore, Darmstadt, Germany) and (B) acetonitrile (Optima ${ }^{\circledR}$ LC/MS Grade, Fisher Scientific, Hampton, New Hampshire, USA). The flow rate of the eluent was $0.3 \mathrm{~mL} \mathrm{~min}^{-1}$. The eluent gradient program was $5 \% \mathrm{~B}$ for $1 \mathrm{~min}$, from $5 \% \mathrm{~B}$ to $100 \%$ $\mathrm{B}$ in $16 \mathrm{~min}, 100 \% \mathrm{~B}$ for 2 min constant and from $100 \% \mathrm{~B}$ to $5 \% \mathrm{~B}$ in $0.1 \mathrm{~min}$, and $5 \% \mathrm{~B}$ was then kept constant for $3.9 \mathrm{~min}$. This analytical procedure can be used for amines, too, as described in van Pinxteren et al. (2019). The FAA concentrations were determined via external calibration. Since no chiral column was used in the UHPLC separation, we cannot differentiate between L- and D-amino acids in our ambient samples. Each seawater sample was measured as a duplicate with a relative standard deviation $<10 \%$ and under consideration of the blank samples for seawater. They consist of high-purity water, which was filled in pre-cleaned plastic bottles and handled the same as the seawater samples. The limit of quantification (LOQ) of the individual FAAs in seawater samples is in good agreement with the FAA analysis of seawater samples (e.g., Kuznetsova et al., 2004) and are listed in Table S1. The LOQs were mostly below $10 \mathrm{nmol} \mathrm{L}^{-1}$; however, GABA and Met exhibited LOQs of 24.2 and $16.8 \mathrm{nmol} \mathrm{L}^{-1}$, respectively (due to high blank values). A quantification of some FAAs in seawater, mainly in the ULW with its generally lower FAA concentrations compared to the SML, is therefore partly limited.

\subsubsection{Aerosol particle filter analyses}

For analyzing the size-segregated aerosol particle samples, the substrate material of each stage was extracted in $3 \mathrm{~mL}$ of high-purity water (Millipore Elix 3 and Element A10, Merck Millipore, Darmstadt, Germany). The aqueous particle extracts were divided into aliquots for the analysis of water-soluble organic carbon and total dissolved nitrogen (WSOC/TDN), inorganic ions, and amino acids. The aliquots for WSOC/TDN were first filtered with a $0.45 \mu \mathrm{m}$ syringe filter and then determined by a TOC-VCPH analyzer (Shimadzu, Japan), as described in van Pinxteren et al. (2012). For the analysis of inorganic ions, the aliquots $(250 \mu \mathrm{L})$ were filtered $(0.45 \mu \mathrm{m}$ syringe filter) and investigated using ion chromatography (ICS3000, Dionex, Sunnyvale, CA, USA), as outlined in Müller et al. (2010). The aliquot $(1.5 \mathrm{~mL})$ of the aqueous particle extracts for FAA analysis was reduced to several microliters with a vacuum concentrator at $T=30^{\circ} \mathrm{C}$ (miVac sample Duo, GeneVac Ltd., Ipswich, United Kingdom), filtered using $0.2 \mu \mathrm{m}$ syringe filters, and derivatized and analyzed using the UHPLC/ESI-Orbitrap-MS method, as explained in Sect. 2.2.1 for seawater samples. FAA concentrations were calculated via external calibration; each sample was measured in duplicate with a relative standard deviation 
$<10 \%$ and under consideration of field blanks. For generating field blanks, pre-baked aluminum foils without active sampling were cut and prepared the same as field samples, including extraction and measurements for WSOC/TDN, inorganic ions and amino acid analysis. All values presented here for aerosol particle samples are field blank corrected. The LOQs of the individual FAAs in aerosol particle samples are listed in Table $\mathrm{S} 1$ and are in good agreement with the sensitivity of other analytical methods for FAAs in aerosol particles (e.g., Matsumoto and Uematsu, 2005). Although a variance in LOQs between the individual FAAs is apparent, FAAs with relatively high LOQs $\left(39.5 \mathrm{pg} \mathrm{m}^{-3}\right)$ such as Ala, GABA, and Asp in submicron and supermicron aerosol particles could be quantified (as discussed in Sect. 3.2 and 3.4).

The analysis of mineral dust tracers on nucleopore foils sampled with the Berner impactor was performed with the total reflection X-ray fluorescence S2 PICOFOX (Bruker AXS, Berlin, Germany) equipped with a Mo-X-ray source on polished quartz substrates, as can be seen in Fomba et al. (2013). The particulate mass (PM) of the aerosol particle samples was determined by weighing the filter before and after sampling (van Pinxteren et al., 2015). Back trajectory analyses provided information regarding the origins of air masses. Back trajectories of $7 \mathrm{~d}$ were calculated on an hourly basis within the sampling intervals using the NOAA HYSPLIT model (HYbrid Single-Particle Lagrangian Integrated Trajectory; http://www.arl.noaa.gov/ready/hysplit4. html (last access: 21 December 2020), 26 November 2016) in the ensemble mode at an arrival height of $500 \pm 200 \mathrm{~m}$ (van Pinxteren et al., 2010); van Pinxteren et al. (2020) provide more details. The calculated backward trajectories are representative of both aerosol particle sampling stations (CVAO and MV).

\subsubsection{Cloud water analyses}

The cloud water samples were processed the same way as seawater samples for the analysis of DOC/TDN and inorganic ions (Sect. 2.2.1). For the amino acid analysis, the volume of cloud water samples $(44 \mathrm{~mL})$ was reduced to several milliliters using a vacuum concentrator at $T=$ $30^{\circ} \mathrm{C}$ (miVac sample Duo, GeneVac Ltd., Ipswich, United Kingdom). After the filtration with $0.2 \mu \mathrm{m}$ syringe filters (Acrodisc-GHP; 25 mm, Pall Corporation, New York, USA), an aliquot of the prepared cloud water was derivatized based on the AccQ-Tag ${ }^{\mathrm{TM}}$ precolumn derivatization method (Waters, Eschborn, Germany). The analytical measurements of the derivatized FAAs were performed with UHPLC/ESIOrbitrap-MS (Sect. 2.2.1). The cloud water samples were measured as duplicates with a relative standard deviation $<10 \%$. Via external calibration, the amino acid concentrations under the consideration of the cloud water blanks were calculated. The blank samples of cloud water were generated by rinsing the pre-cleaned Teflon rods with high-purity water after their installation in the cloud water sampler. Then, the blank samples were handled the same way as the field cloud water samples, including the derivatization and analytical separation, as described in Sect. 2.2.1. Overall, the LOQs of the individual FAAs in cloud water samples are in good agreement with the reported sensitivity of the FAA analysis in cloud water (Bianco et al., 2016) and listed in Table S1. Since the LOQs of the FAAs in cloud water are below $0.3 \mathrm{ng} \mathrm{m}^{-3}$ and often below $0.06 \mathrm{ng} \mathrm{m}^{-3}$, a limitation of the FAA composition in cloud water due to the LOQs is rather unlikely despite the variance of FAA concentrations (11.2$489.9 \mathrm{ng} \mathrm{m}^{-3}$ ) in cloud water (Sect. 3.3). To calculate the atmospheric concentration of FAAs in cloud water, the measured concentrations were multiplied by the measured liquid water content (LWC) of the clouds, as Fomba et al. (2015) applied previously.

\subsubsection{Enrichment factors}

The enrichment factor in the SML ( $\left.\mathrm{EF}_{\mathrm{SML}}\right)$ was calculated by dividing the concentration of the analyte in the SML with the concentration of the analyte in the ULW using the following Eq. (1):

$\mathrm{EF}_{\mathrm{SML}}=\frac{c(\text { analyte })_{\mathrm{SML}}}{c(\text { analyte })_{\mathrm{ULW}}}$.

Accordingly, both an enrichment in the SML with $\mathrm{EF}_{\mathrm{SML}}>1$ and a depletion in the SML with $\mathrm{EF}_{\mathrm{SML}}<1$ are indicated.

The FAA concentration in the ULW was assumed to be based on the concentration (LOQ/2) of individual amino acids for seawater samples from the same campaign day when individual FAAs could be quantified in the SML samples but not in the corresponding ULW ones due to FAA values below the LOQs (listed in Table S1). For the calculation of this estimated $\mathrm{EF}_{\mathrm{SML}}$, specially marked in the following, the concentration of $25.2 \mathrm{nmol} \mathrm{L}^{-1}$ was used for $c$ (analyte) $)_{\mathrm{ULW}}$ in Eq. (1).

To calculate the enrichment factor of the individual analytes in different matrices $(\mathbf{M})$, the concentration of the analyte in matrix $1\left(\mathbf{M}_{1}\right)$ relative to the sodium $\left(\mathrm{Na}^{+}\right)$concentration in $\mathbf{M}_{1}$ was divided by the analyte concentration in matrix $2\left(\mathbf{M}_{2}\right)$ relative to the $\mathrm{Na}^{+}$concentration in $\mathbf{M}_{2}$ using Eq. (2):

$\mathrm{EF}_{M_{1}}=\frac{c(\text { analyte })_{M_{1}} / c\left(\mathrm{Na}^{+}\right)_{M_{1}}}{c(\text { analyte })_{M_{2}} / c\left(\mathrm{Na}^{+}\right)_{M_{2}}}$.

The aerosol enrichment factor $\left(\mathrm{EF}_{\mathrm{aer}}\right)$ was calculated in each of the five Berner stages ( $B_{x}$ with $x=1-5$ as $\mathbf{M}_{1}$ ) using the respective analyte or $\mathrm{Na}^{+}$concentration in relation to the SML or the ULW as $\mathbf{M}_{2}$. For this purpose, the aerosol particle concentrations, typically sampled at a $24 \mathrm{~h}$ interval, were combined with SML and ULW concentrations which had been collected during the aerosol particle sampling period. The analyte concentration in each size class of sizesegregated aerosol particle samples (B1-5) was combined with the analyte concentration in SML and ULW. The calculation of the $\mathrm{EF}_{\text {aer }}$ was limited to the availability of data 
in both matrices - size-segregated aerosol particles and SML and/or ULW samples. The $\mathrm{EF}_{\text {aer }}$ could only be calculated if both the analyte concentration and the sodium concentration could be quantified in the size-segregated aerosol particles and the corresponding SML and/or ULW samples. To calculate the enrichment factor in cloud water $\left(\mathrm{EF}_{\mathrm{CW}}\right)$, the concentration of the analyte and of $\mathrm{Na}^{+}$in the cloud water was considered as $\mathbf{M}_{1}$ and those of the SML or the ULW as $\mathbf{M}_{2}$. The determination of $\mathrm{EF}_{\text {aer }}$ was possible for $n=3$ samples on the basis of both SML and ULW. The $\mathrm{EF}_{\mathrm{CW}}$ could only be determined for $n=1$ sample though, based on the SML and/or ULW measurements. Section 3.4 discusses both the $\mathrm{EF}_{\mathrm{aer}}$ and the $\mathrm{EF}_{\mathrm{CW}}$ in more detail.

\section{Results and discussion}

\subsection{Seawater samples}

\subsubsection{Free amino acids in seawater samples}

Free amino acids (FAAs) were measured in the seawater as a source region of FAAs in primary marine aerosol particles. Figure $1 \mathrm{~b}$ shows the measured $\sum$ FAA concentration in the SML and the ULW samples, together with their enrichment factor $\mathrm{EF}_{\mathrm{SML}}$ (Eq. 1).

$\sum F A A$ included all investigated amino acids (listed in Sect. 2.2.1) except for Met, Gln and GABA. As discussed in Sect. 2.2.1, GABA and Met have the highest LOQs of the analytical method used here, which may be one reason why these two analytes could not be quantified in the seawater samples (ULW and SML).

Looking at the percentage composition within the ULW (10.1\% hydrophilic, $57.0 \%$ neutral, $32.8 \%$ hydrophobic) and the SML (10.6\% hydrophilic, $61.7 \%$ neutral, $27.7 \%$ hydrophobic), the values are similar to each other. However, the concentration of $\sum$ FAA varied between 0.01 and $1.10 \mu \mathrm{mol} \mathrm{L}^{-1}$ in the ULW and between 0.13 and $3.64 \mu \mathrm{mol} \mathrm{L}^{-1}$ in the SML. Interestingly, in the second half of the campaign, the $\sum$ FAA concentration was higher than in the first part. Previous studies in different oceanic areas (Kuznetsova and Lee, 2002; Kuznetsova et al., 2004; Reinthaler et al., 2008; van Pinxteren et al., 2012; Engel and Galgani, 2016) have already reported a generally strong variability in $\sum$ FAA concentrations, especially in the SML. Reinthaler et al. (2008) concluded that the SML in the open ocean is a highly variable environment with high concentrations of dissolved FAAs and their high enrichment in the SML is without clear diel variations in their concentrations. Nevertheless, the variance of the $\sum F A A$ concentrations in the SML and ULW observed here could neither be explained by the variance of DOC or TDN values nor by wind speed and chl $a$ concentrations (see Fig. 1, Tables S2, S5) since no correlation between these parameters and the concentration or enrichment of FAAs was found. This is consistent with other publications which observed that the amino acid concentration in seawater is not related to environmental parameters such as wind, humidity and light (Kuznetsova et al., 2004; van Pinxteren et al., 2012). The results of the individual FAA concentrations in seawater (ULW, SML) and their $\mathrm{EF}_{\mathrm{SML}}$, listed in Table S3, show clear differences between the individual amino acids and the amino acid classes. The most highly enriched amino acids in the SML are the neutral ones with values of up to 203 compared to the hydrophilic $\left(\mathrm{EF}_{\mathrm{SML}}\right.$ : 2-98) and hydrophobic (EF $\mathrm{ESL}_{\mathrm{SM}}$ : 1-96) amino acids. This may be related to the fact that Ser, Thr and Gly, as part of the neutral amino acids, are main components of cell wall proteins (Hecky et al., 1973). The direct release of FAAs through cell lysis and the associated destruction of the cell wall can thus explain the increased enrichment of neutral amino acids in the SML. Our study confirmed that the SML is often non-uniformly enriched with FAAs as outlined from previous observations (Kuznetsova and Lee, 2002; Reinthaler et al., 2008; van Pinxteren et al., 2012; Engel and Galgani, 2016). Different factors, such as the transport of FAAs from the ULW to the SML, the in situ production by an extracellular hydrolysis of CAA or a direct release of FAAs by cell lysis, probably cause the observed enrichment of FAAs in the SML. Kuznetsova and Lee (2002) showed that the rapid extracellular hydrolysis of CAAs in the SML was not the cause of the non-uniform enrichment in the SML. Moreover, they suggested that the intracellular pools of organisms rich in dissolved free and combined amino acids (DFAAs and DCAAs) compared to seawater can be leached out by stressed microorganisms, resulting in the release of DFAAs which in turn influences the pools of both DFAAs and DCAAs in seawater. Based on previous studies, the transportation and releasing mechanisms seem most likely to be the reasons for the observed enrichment of FAAs. However, further experiments are required to finally elucidate the most important drivers causing the enrichment.

Altogether, it can be concluded that there is some variability in the FAA concentration in the SML and in the ULW with a clear trend of its strong enrichment in the SML. The fact that the FAA concentrations were in accordance with the ones measured at the same location in November $2013\left(0.64 \mu \mathrm{mol} \mathrm{L}^{-1}\right.$; Table S4) supports the suggestion that the FAA concentrations reported here can be considered representative of the NATR region as part of the North Atlantic Ocean. These concentrations are generally similar when comparing them to FAA concentrations in other marine regions (Kuznetsova and Lee, 2002; Reinthaler et al., 2008). Reinthaler et al. (2008) considered concentrations of dissolved FAAs of $0.02-0.13 \mu \mathrm{mol} \mathrm{L}^{-1}$ (ULW) and of $0.43-$ $11.58 \mu \mathrm{mol} \mathrm{L}^{-1}$ (SML) in the subtropical Atlantic Ocean, as well as values of $0.07-0.60 \mu \mathrm{mol} \mathrm{L}^{-1}$ (ULW) and of $0.77-$ $3.76 \mu \mathrm{mol} \mathrm{L}^{-1}$ (SML) in the western Mediterranean Sea. Consequently, the FAA concentrations in the NATR region, with its very low surface chlorophyll and a greater annual than seasonal variability are on the same order of magnitude 

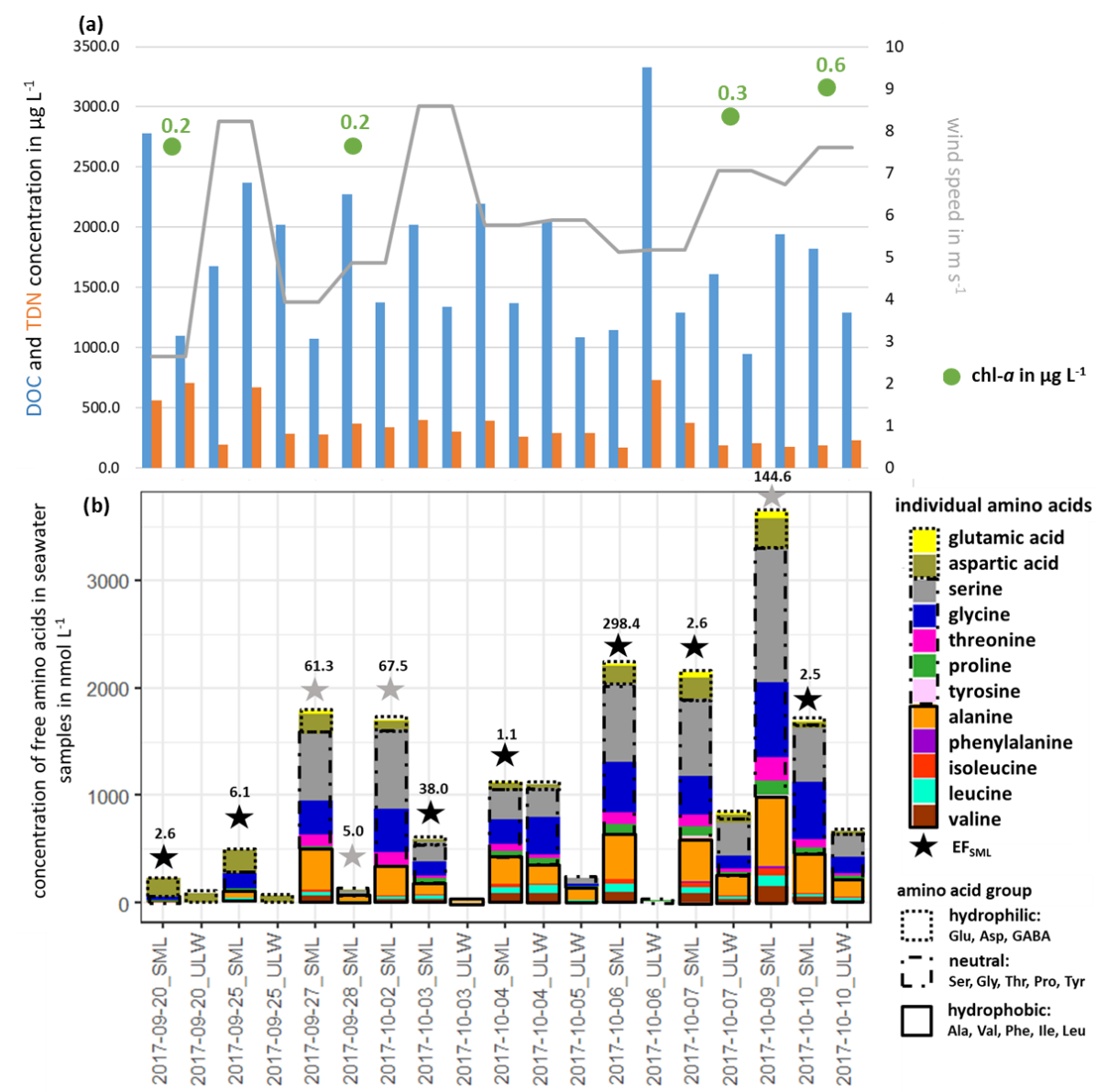

Figure 1. (a) DOC, TDN and chl $a$ concentrations in seawater and wind speed and (b) individual FAA concentration in the seawater samples and the enrichment factor $\mathrm{EF}_{\mathrm{SML}}$ of $\sum \mathrm{FAA} . \mathrm{EF}_{\mathrm{SML}}$ is based on measurements (black stars), $\mathrm{EF}_{\mathrm{SML}}$ is based on LOQ/2 estimation (gray stars).

compared to other marine regions (i.e., subtropical Atlantic and western Mediterranean Sea; Reinthaler et al., 2008).

\subsubsection{Contribution of FAAs to DOC and TDN content in seawater}

DOC and TDN concentrations and their enrichment in the SML $\left(\mathrm{EF}_{\mathrm{SML}}\right)$ are listed in Table S5. The contribution of $\sum$ FAA to DOC or TDN in seawater has been calculated (taking into account the carbon and nitrogen content of the amino acids; Table S6) and is also listed in Table S5. The carbon content of $\sum$ FAA contributed to the DOC with values between $0.1 \%$ and $7.6 \%$ in the seawater samples and a median of $2.4 \%(n=17)$, differing between $2.8 \%(n=11)$ in the SML and $1.8 \%(n=6)$ in the ULW samples. Looking at the nitrogen content from $\sum$ FAA to TDN in the seawater samples, $0.1 \%-42.4 \%$ of the TDN consisted of $\sum$ FAA with a median of $8.3 \%(n=18)$. In the SML, $\sum$ FAA contributed on average $11.9 \%(n=11)$ to TDN, whereas they contributed in the ULW $3.2 \%(n=7)$. The observed daily variations within the contribution of $\sum F A A$ to DOC/TDN, result from the daily variations in $\sum F A A$ concentrations in seawater (Fig. 1) and of DOC/TDN (Table S5). In the SML of the Atlantic Ocean and the western Mediterranean Sea, the DFAAs contributed $\sim 12 \%$ of the DOC and $\sim 30 \%$ of the dissolved organic nitrogen (DON) (Reinthaler et al., 2008). Our results regarding the contribution to DOC were of the same order of magnitude but slightly lower than those of Reinthaler et al. (2008).

\subsection{Size-segregated aerosol particles}

\subsubsection{Size-segregated aerosol particles at the CVAO}

\section{First indications for aerosol particle origin}

To obtain a first indication of the particle origin that might help to explain the differences in the particle composition concerning amino acids, the particles were associated with the origin of the air masses and with marine and dust tracers. Overall, the CVAO station experienced northeasterly trade winds during this campaign, which are typical for this sea- 
son within this region (Fomba et al., 2014; van Pinxteren et al., 2020). According to physical and chemical specifications such as the air mass origins, particulate MSA concentrations and MSA/sulfate ratios, as well as particulate mass concentrations of dust tracers, aerosol particles predominantly of marine origin with low to medium dust influences were observed. The dust and marine tracers of the aerosol particles considered here are discussed in more detail in the Supplement (Table S8 and in "aerosol particles: dust and marine tracers"). Further information on the classification of the air masses and distinct concentrations of dust tracers are given in the overview paper of this campaign (van Pinxteren et al., 2020).

\section{Free amino acids in size-segregated aerosol particles: concentrations}

The lower panel of Fig. 2b shows the atmospheric concentration of FAAs in each Berner stage at the CVAO, whereas the upper panel represents the concentration in the submicron, the supermicron and PM aerosol particle size ranges. In the submicron aerosol particles, the concentration of $\sum$ FAA was between $1.3 \mathrm{ng} \mathrm{m}^{-3}$ (1 October 2017) and $6.3 \mathrm{ng} \mathrm{m}^{-3}$ (7 October 2017). While the concentration $\sum$ FAA varied between $0.2 \mathrm{ng} \mathrm{m}^{-3}$ (6 October 2017) and $1.4 \mathrm{ng} \mathrm{m}^{-3}$ (22 September 2017) in the supermicron size range, the highest atmospheric concentrations of $\sum$ FAA were found in the submicron aerosol particles (mean of $3.2 \mathrm{ng} \mathrm{m}^{-3}$ ) compared to the supermicron ones (mean of $0.6 \mathrm{ng} \mathrm{m}^{-3}$ ). Daily variations in the $\sum$ FAA content of the investigated size-segregated aerosol particle samples were observed; the $\sum$ FAA tended to increase slightly throughout the campaign. OM parameterization studies showed that wind speed and chl $a$ concentrations were the most important parameters for the regulation of the OM production in sea spray aerosol particles (Gantt et al., 2011; Rinaldi et al., 2013; van Pinxteren et al., 2017). Correlations between the $\sum$ FAA concentrations of the sizesegregated aerosol particles (considered as submicron, supermicron and $\mathrm{PM}_{10}$ ) and the wind speed were not observed for data reported here (Fig. 2, Table S2). However, the available wind speed and wind direction data represented an average value of $24 \mathrm{~h}$. Therefore, short, pronounced changes in the wind speed that might have affected the amino acid transfer would not have been visible in the averaged wind speed value. The major source of bubbles is whitecaps or breaking waves that occur when the wind speed exceeds $3-4 \mathrm{~m} \mathrm{~s}^{-1}$ (Blanchard, 1975), which was continuously reported during the campaign. Hence, the high wind speeds, together with the constantly observed breaking waves, indicated that the wind intensity in this region might be consistently sufficient to transfer the amino acids from the ocean into the atmosphere. No significant correlation could be observed between the $\sum$ FAA concentration of size-segregated aerosol particle samples (submicron, supermicron and $\mathrm{PM}_{10}$ ) and the chl $a$ concentration in seawater. Nevertheless, the increasing chl $a$ concentration throughout the campaign (Fig. 2, Table S2) could be a reason for the slight increase in the concentrations of $\sum$ FAA in seawater and in submicron aerosol particles, indicating a possible connection between ocean and atmosphere, e.g., the transfer of amino acids from the ocean into the atmosphere.

Overall, the concentrations reported here agree well with other FAA studies on marine aerosol particles. Matsumoto and Uematsu (2005) found averaged total concentrations of dissolved FAAs of $4.5 \mathrm{ng} \mathrm{m}^{-3}$ in aerosol particles (average of $<2.5$ and $>2.5 \mu \mathrm{m}$ ) in the western North Pacific Ocean. Moreover, Wedyan and Preston (2008) observed an average concentration of dissolved FAA of $2.5 \mathrm{ng} \mathrm{m}^{-3}$ on total suspended particles (TSPs) during a transect ship cruise in the Atlantic Ocean. For Antarctic aerosol particles, the observed mean total FAA concentration in size-segregated aerosol particle samples $(<0.49-10 \mu \mathrm{m})$ at the Mario Zucchelli Station was $4.6 \mathrm{ng} \mathrm{m}^{-3}$ (Barbaro et al., 2015). Hence, regarding the sum of FAAs, a striking similarity was found between FAA concentrations in different parts of the ocean that probably underlay different influences (e.g., pristine region in the Southern Ocean, continental-influenced aerosol particles in the North Pacific Ocean).

\section{Free amino acids in size-segregated aerosol particles: composition}

$\sum$ FAA included all investigated amino acids (listed in Sect. 2.2.1) except for Met and Gln, analytes which were not detected in the size-segregated aerosol particle samples. The most abundant FAA was Gly, which was consistently found in submicron and supermicron aerosol particles, followed by Ala and Ser. However, towards the end of the campaign (4-7 October 2017), a high contribution of the hydrophilic FAAs GABA and Asp was detected (shown in the upper panel of Fig. 2b), which caused the slight increase in the total FAA concentration.

The higher complexity of the FAA composition in the submicron aerosol particles could only be determined because the analytical method applied here was able to quantify the individual molecular FAA species. Such differentiation would not be possible with methods that determine the proteins as a sum parameter (e.g., the often applied Bradford method).

The high abundance of Gly in the aerosol particles is in good agreement with the Gly occurrence in other marine studies. Gly seems to be the dominant FAA, independent of whether the particles were sampled in the Arctic (Scalabrin et al., 2012), Antarctic (Barbaro et al., 2015) or in the North Pacific (Matsumoto and Uematsu, 2005) or whether they were attributed to a local marine source (Wedyan and Preston, 2008; Barbaro et al., 2015) or were rather under continental or long-range influences (Matsumoto and Uematsu, 2005). Other abundant FAAs reported at the different locations are arginine (not analyzed here), Ser and Ala; the latter ones are 


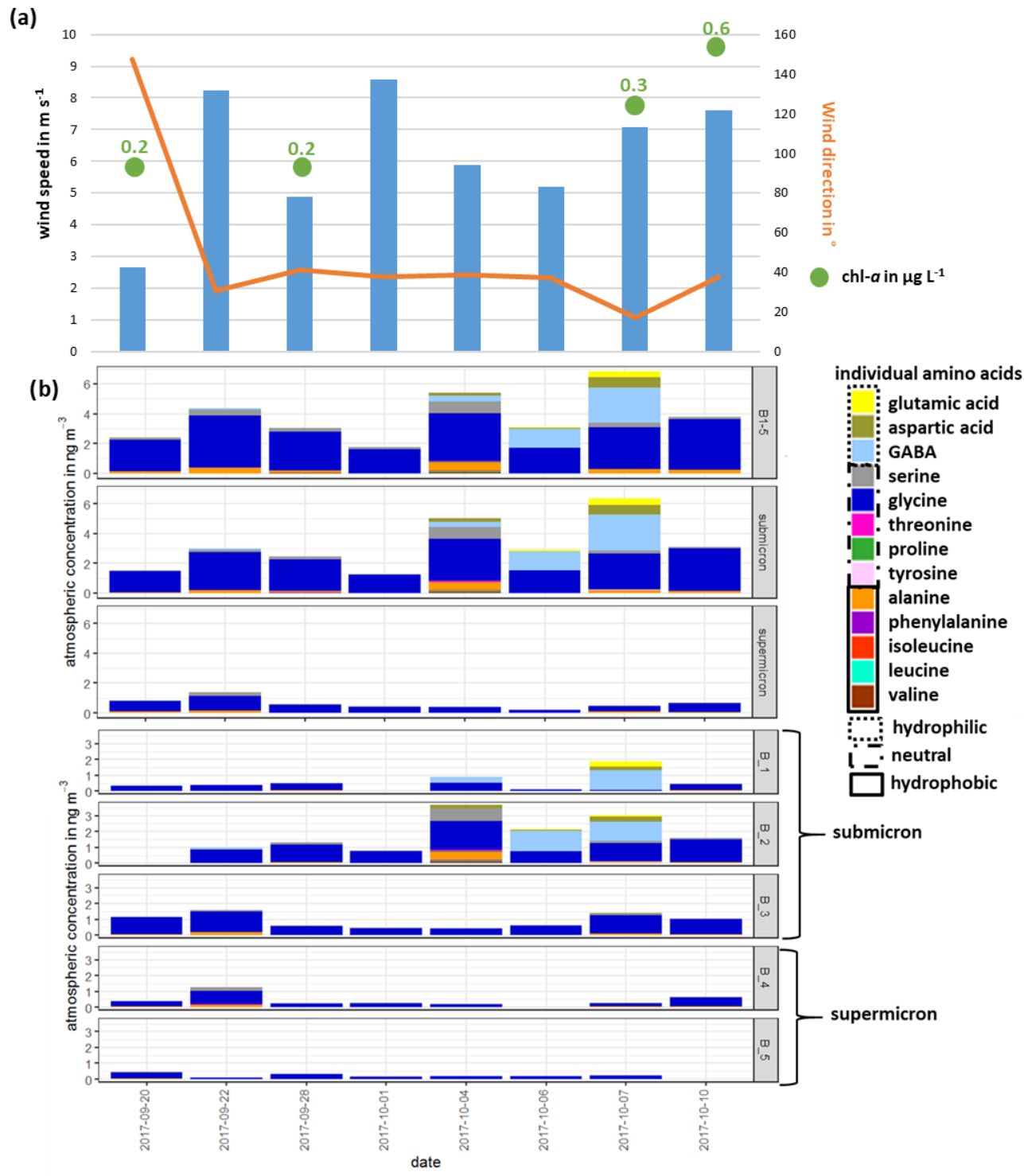

Figure 2. (a) Overview of wind speed and wind direction at the CVAO and the chl $a$ concentration in seawater; (b) atmospheric concentration of individual FAAs: sum of all Berner stages (B1-5) in the submicron and supermicron size ranges (upper panel) and the atmospheric concentration of FAA in all individual Berner stages (lower panel) during the campaign at the CVAO

also dominant FAAs found in the study here reported. Consequently, the usage of the major FAAs as chemical biomarkers seems to be restricted to some extent due to their lack of source specificity. The high abundance of GABA found in the second half of the campaign has neither been partly regarded (i.e., included as a standard compound) in some marine studies nor yet been reported in ambient marine aerosol particles but seems to be special for this location. However, the reasons for the high concentration of hydrophilic FAAs within these respective sampling days remain unclear since no change in the environmental parameters determined (e.g., wind speed, wind direction, chl $a$ concentration; Fig. 2a) was observed. In addition, we considered further FAA physico- chemical parameters, such as the octanol-water partition coefficient $\left(K_{\mathrm{OW}}\right)$, the topological polar surface area (TPSA), which describes the surface activity, and the density (Table S9), to describe the concentration changes. However, no statistically relevant correlations between the FAA concentration or composition and physicochemical parameters were found here either. Our observations could not clarify possible additional (i.e., non-marine) sources leading to the higher concentrations and complexity in the FAA composition. The dynamics behind the varying FAA concentrations and compositions at this location seem to be complex.

Following this hydropathy classification, the submicron aerosol particles consisted on average of $5 \%$ hydrophobic, 
$15 \%$ hydrophilic and $80 \%$ neutral amino acids, while the supermicron aerosol particles contained on average only $7 \%$ hydrophobic and $93 \%$ neutral amino acids (Table S7). During the campaign, an increase in the contribution of hydrophilic amino acids was observed with a maximum of $55 \%$ on 7 October 2017. Barbaro et al. (2015) reported that hydrophilic components were predominant $(60 \%)$ in locally produced marine Antarctic aerosol particles, whereas hydrophobic compounds were the rather dominant aerosol particles collected at the continental station (23\% and $27 \%)$. The relatively high content of hydrophilic FAAs during certain periods of the campaign points at least to some influence of local oceanic sources.

\section{Contribution of FAA to WSOC and water-soluble organic nitrogen}

In consideration of the carbon or nitrogen content of the amino acids (Table S6), the contribution of $\sum$ FAA to WSOC and water-soluble organic nitrogen (WSON) in the sizesegregated aerosol particles was calculated (Table S10). In the submicron size range, $\sum$ FAA contributed up to $5.3 \%$ (average $1.1 \%$ ) to WSOC, while in the supermicron range, $\sum$ FAA only contributed up to $0.04 \%$ to WSOC. Looking at $\sum$ FAA's total contribution to WSOC $\left(\mathrm{PM}_{10}\right), 0.7 \%$ of WSOC consists of $\sum F A A$, which is in good agreement with the value of the study by Mandalakis et al. (2011). Considering the nitrogen content of the amino acids, $\sum$ FAA contributed to the estimated WSON (WSON $=25 \%$ of measured TDN concentrations according to Lesworth et al., 2010) an average of $0.4 \%$ in the submicron and of $0.05 \%$ in the supermicron size ranges. The observed daily variations in the contribution of $\sum$ FAA to WSOC/WSON were derived from the daily variations in the atmospheric concentrations of $\sum$ FAA (Fig. 2) and of WSOC/ WSON (Table S10). In summary, $\sum$ FAA contributed up to $5.3 \%$ to WSOC and $1.8 \%$ to WSON when it comes to the submicron aerosol particles (7 October 2017) and up to $0.15 \%$ to WSOC and $0.1 \%$ to WSON for the supermicron aerosol particles. These percentages were on the same order of magnitude as for other organic compound groups, e.g., amines. It was shown by van Pinxteren et al. (2019) that amines contributed on average $5 \%$ to the submicron WSOC content in marine aerosol particles. The percentage of $\sum$ FAA to WSOC (up to $5.3 \%$ ) in the submicron aerosol particles especially demonstrated that FAA comprised a substantial fraction of submicron WSOC in marine aerosol particles.

\subsubsection{Size-segregated aerosol particles at MV}

From the MV samples, FAAs and additional parameters such as PM, WSOC, sodium and MSA were investigated. The results are listed in Table S11. The submicron aerosol particles at MV had an averaged $\sum F A A$ concentration of $1.5 \mathrm{ng} \mathrm{m}^{-3}\left(0.8-1.9 \mathrm{ng} \mathrm{m}^{-3}\right)$ which was about 3 times lower compared to the $\sum$ FAA concentration at the CVAO. The $\sum F A A$ concentration in the supermicron aerosol particles at MV $\left(1.2 \mathrm{ng} \mathrm{m}^{-3} ; 0.2-2.9 \mathrm{ng} \mathrm{m}^{-3}\right)$ was similar to the respective concentration at the CVAO. Additional online measurements of particle size number distributions (PSNDs) at the CVAO and MV, described in Gong et al. (2020), were in good agreement with one another during cloud-free times. This indicated that, for cloud-free conditions, the aerosol particles measured at ground level $(30 \mathrm{~m})$ within the IBL, which is mainly below $30 \mathrm{~m}$ (Niedermeier et al., 2014), represented the aerosol particles at cloud level. Thus, the aerosol particles within the marine boundary layer (MBL) were well mixed, and Mt. Verde was most of the time within the MBL (van Pinxteren et al., 2020). However, as described above, the Berner measurements were (continuously) taken during cloud-free and during cloudy times. The concentration and composition of the aerosol particles can therefore be affected by the clouds that formed and disappeared consistently during the sampling period of the aerosol particles on Mt. Verde (for further details on the frequency of the cloud events see Gong et al., 2020, and van Pinxteren et al., 2020). There was also no rain during the entire campaign. Furthermore, aging processes may occur during the upwind of the aerosol particles from the CVAO to the MV station, which takes about $4 \mathrm{~h}$ considering an average vertical wind of $5 \mathrm{~cm} \mathrm{~s}^{-1}$ (van Pinxteren et al., 2020). The particles at MV exhibited lower particle masses, as well as lower concentrations of the aerosol particle constituents. The decrease in concentrations of $\sum F A A$, PM, sodium, MSA and WSOC was reduced by a factor of 3 to 4 with respect to the submicron aerosol particles. However, no uniform depletion ratio between their concentrations at the CVAO and MV was found for the supermicron aerosol particles (Table S11). While the PM of the supermicron particles was reduced by a factor of 4 at MV (similar to the submicron aerosol particles), sodium and WSOC were depleted more strongly (factor of 11-12) compared to their respective concentrations at the CVAO. This suggests that the submicron particles were rather uniformly affected and depleted, likely by cloud processes, while the supermicron particles were influenced by clouds, and potentially other sources, in a non-uniform way. Nevertheless, the abundance of the marine tracers (sodium, MSA), together with the presence of FAAs in the aerosol particles (which mainly had a similar composition compared to the oceanic and ground-based particulate FAAs), indicated an oceanic contribution to the aerosol particles at cloud level.

\subsection{Cloud water samples}

The concentration of FAAs in cloud water (Fig. 3, Table S12) was, although varying, always significantly higher than the aerosol particles (Table S8) and several orders of magnitude above the LOQs (Table S1). The individual atmospheric concentration of FAAs in cloud water was calculated based on the measured liquid water content (LWC) (Sect. 2.2.3 and 
Table S12). The $\sum$ FAA concentrations varied strongly between 11.2 and $489.9 \mathrm{ng} \mathrm{m}^{-3}$, as shown in Fig. 3 .

The inorganic marine tracers in cloud water $\left(\mathrm{Na}^{+}\right.$: $5.7 \mu \mathrm{g} \mathrm{m}^{-3}$; MSA: $25.1 \mathrm{ng} \mathrm{m}^{-3}$; Table S12) were also present in higher concentrations compared to the aerosol particle samples at the CVAO (submicron: $\mathrm{Na}^{+}: 72.3 \mathrm{ng} \mathrm{m}^{-3}$; MSA: $6.0 \mathrm{ng} \mathrm{m}^{-3}$ ) and MV (submicron: $\mathrm{Na}^{+}: 17.0 \mathrm{ng} \mathrm{m}^{-3}$; MSA: $1.8 \mathrm{ng} \mathrm{m}^{-3}$; Table S11). The concentrations of cloud water sulfate (average: $2.9 \mu \mathrm{g} \mathrm{m}^{-3}$; Table S12) and sodium were higher than in cloud water samples collected at East Peak in Puerto Rico, which can be seen in Gioda et al. (2009). Our observed carbon concentration of FAAs in cloud water at the MV station was between 17 and $757 \mu g \mathrm{CL}^{-1}$ and on the same order of magnitude as in a previous study of cloud water sampled on top of the Puy de Dôme mountain, inland of France $\left(211 \pm 19 \mu \mathrm{g} \mathrm{CL}^{-1}\right.$; Bianco et al., 2016), but showed a higher variance. Besides the concentration, the composition of FAAs in cloud water also showed a high variability in the study presented here. In cloud water samples with $\sum$ FAA $<65 \mathrm{ng} \mathrm{m}^{-3}$, Gly was usually dominant, followed by Ser. However, cloud water samples with $\sum$ FAA $>290 \mathrm{ng} \mathrm{m}^{-3}$ showed a higher complexity in FAA composition, including the concentrations of Asp and Ala. Other abundant FAAs were Thr, Leu and Ile. In terms of the hydropathy classification, the first part of the campaign (27 September-5 October 2017) was dominated by neutral FAAs, whereas a sudden increase in the hydrophilic FAAs was observed in its second part (6-8 October 2017). Comparative studies on the FAA composition of cloud water in the marine environment are lacking, but especially in the second part of the campaign, it pointed to a local marine (biogenic) influence. The high concentrations of Asp might be related to diatoms and zooplankton in seawater (Hammer and Kattner, 1986). Scalabrin et al. (2012) reported local marine sources for Ile, Leu and Thr detected in aerosol particles, whereas Mashayekhy Rad et al. (2019) suggested coastal and marine phytoplankton and bacteria as possible sources for these amino acids. Therefore, the FAA composition might be related to an oceanic transfer via bubble bursting and/or microbial in situ production. Interestingly, GABA, which was highly abundant in the aerosol particles maybe due to biogenic production, was not present in the cloud water samples. The presence of the marine tracers (sodium, MSA) in cloud water supports a coupling to oceanic sources. In addition, the majority of low-level clouds were formed over the ocean, and ocean-derived components are expected to have some influence on cloud formation (van Pinxteren et al., 2020). Nevertheless, contributions from the desert and other non-marine sources cannot be excluded.

The reason for the high concentrations of FAAs in cloud water (compared to the oceanic and aerosol particle concentrations) remains speculative to date and will be the subject of further studies. Altogether, the in situ formation of FAAs in cloud water by chemical abiotic processes in the cloud or by atmospheric biogenic formation, as proposed by Jaber Jaber et al. (2020), as well as by selective enrichment processes and $\mathrm{pH}$-dependent chemical reactions, might be potential additional sources besides aerosol particles.

\subsection{Concerted measurements of FAA in the marine compartments (seawater, aerosol particles and cloud water)}

Only a few studies which concern the simultaneous investigation of FAAs in the marine compartments - seawater, aerosol particles and cloud water - using concerted measurements are present to date; most of them measured artificially the aerosol particles generated. Kuznetsova et al. (2005) characterized proteinaceous compounds in marine ambient aerosol particles, in generated aerosol particles and in corresponding SML samples. Rastelli et al. (2017) investigated the transfer of OM (sum parameter for lipids, carbohydrates and proteins) from the ocean surface into marine aerosol particles under controlled conditions using a bubble-bursting experimental system. In previous studies, the transfer of microorganisms from the ocean to the aerosol particles could be reported (Aller et al., 2005; Pósfai et al., 2003), and even in submicron marine aerosol particles, viruses and prokaryotes were present (Rastelli et al., 2017).

Within the study presented here, a simultaneous sampling of all marine matrices - seawater (ULW, SML), sizesegregated aerosol particles (CVAO, MV) and cloud water samples - could be obtained for a period between 4 and 7 October 2017 comprising six blocks of size-segregated aerosol particles (three at the CVAO and three at MV), three seawater samples (three SML and three ULW) and one cloud water sample (7 October 2017; 07:48-11:48 local time, GMT -1). For these sampling intervals, the fractional residence time of the air masses was mainly above water, and the mass concentration of trace metals and inorganic marine tracers (sodium, MSA) (Table S8) strongly suggests a dominant marine origin of air masses. Sources other than marine (dust, continental) are, by contrast, of minor importance during this sampling period. The averaged values of these sampling days represent a case study to combine and compare the FAAs in all matrices to investigate a possible transfer of FAAs from the ocean into the atmosphere and a possible transport of FAAs within the atmosphere. The comparability of the different matrices (e.g., seawater samples as a spot sample, aerosol particle samples covering a $24 \mathrm{~h}$ period) is discussed in Fig. S2.

The averaged FAA composition of this case study in all marine compartments is shown in Fig. 4. The high complexity of FAAs observed in seawater was also found in the aerosol particles, as well as in cloud water, and generally shows a high similarity between FAAs in the different compartments. All marine compartments contained Gly, Ser, Glu and Ala as dominant species, i.e., representatives of the hydrophilic, neutral and hydrophobic groups. However, the percentage contribution of the individual FAAs to the $\sum F A A$ varies within the different compartments. 


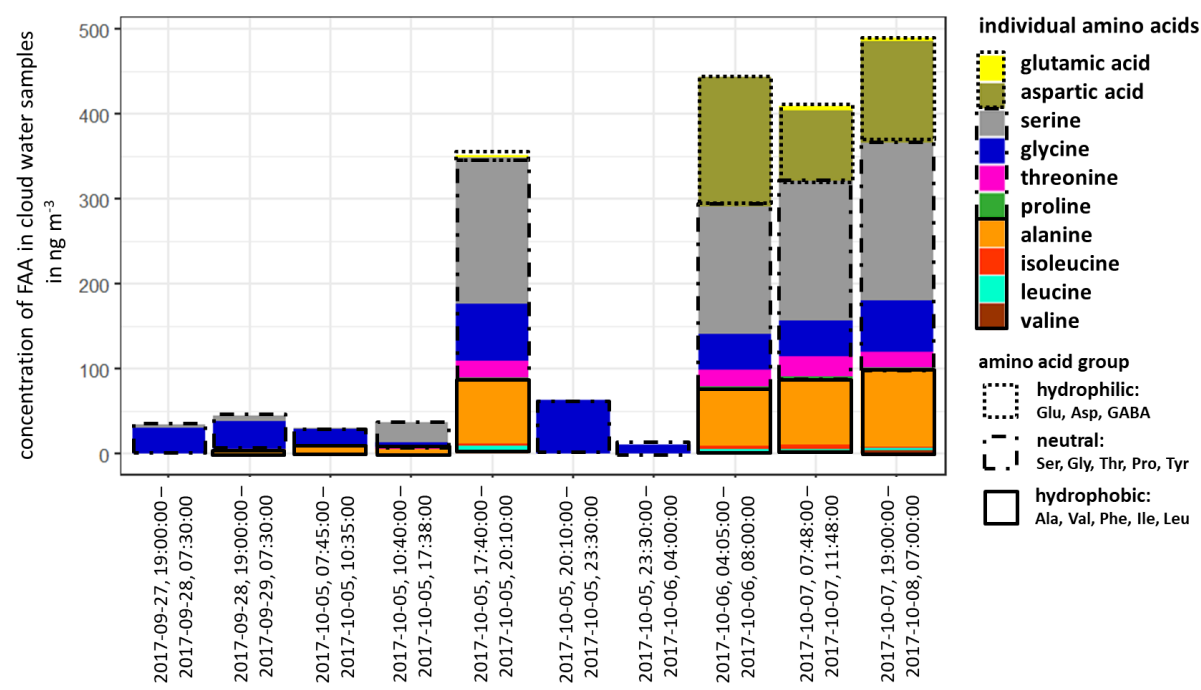

Figure 3. Concentration of individual FAAs in cloud water samples at the MV station (in $\mathrm{ng} \mathrm{m}^{-3}$ ). The time represents the local start and end times of the cloud water sampling.

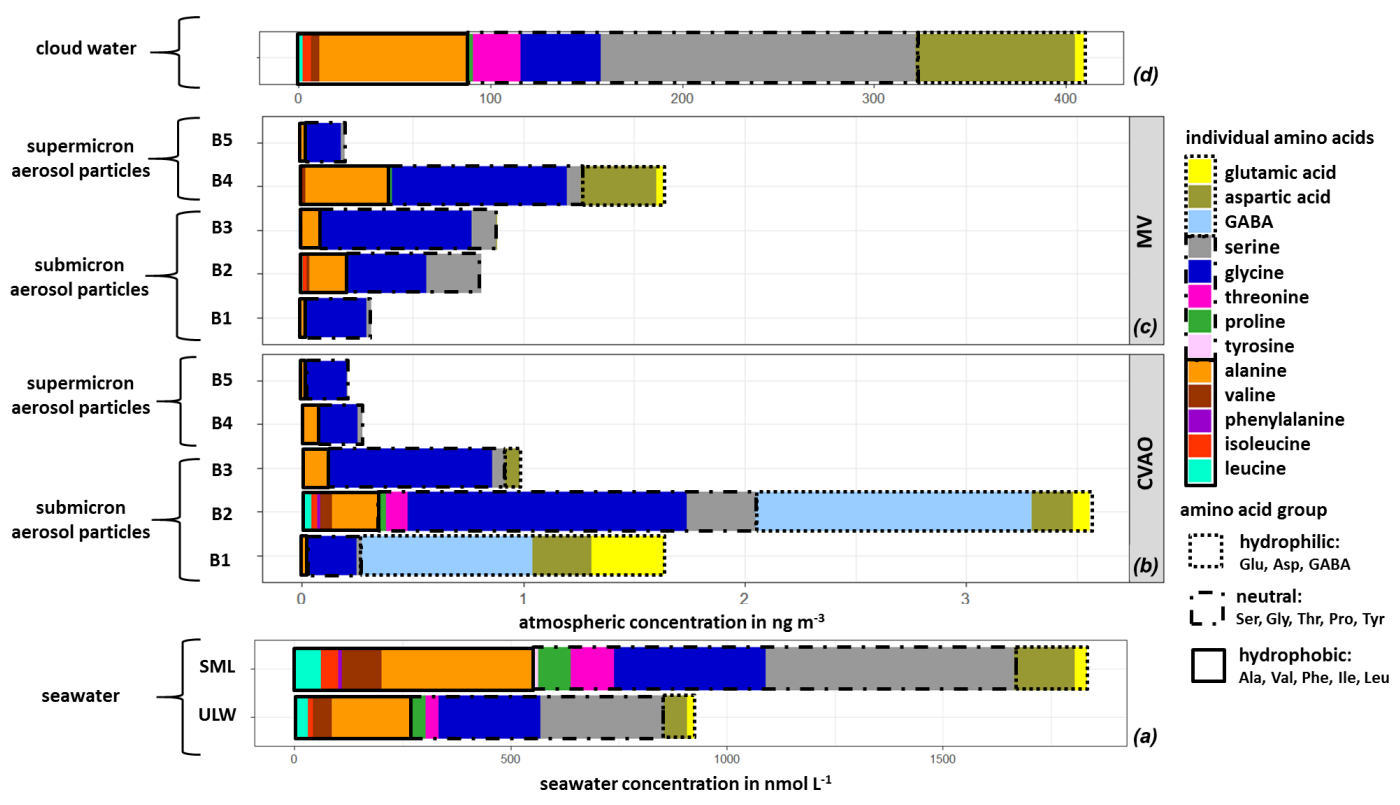

Figure 4. Case study: individual FAA concentrations in (a) seawater samples (ULW, SML; in nmol $\mathrm{L}^{-1}$ ), in (b) size-segregated aerosol particle samples at the CVAO and (c) at the MV station (size range: $0-4 \mathrm{ng} \mathrm{m}^{-3}$ ) and in (d) cloud water samples (size range: $0-400 \mathrm{ng} \mathrm{m}^{-3}$ ).

Representatives of the hydrophilic, neutral, hydrophobic and aromatic amino acids are discussed below with respect to their distribution within the different marine matrices and with respect to a potential transfer. For a better comparison of the individual amino acids, the mean life time $\tau$ of the amino acids in the CVAO ("remote aerosol case") and in the MV ("remote cloud case") aerosol particle samples was considered, as described in Table S13. The mean life time $\tau$ of the individual amino acids depends on the $\mathrm{pH}$-dependent rate constant $\mathrm{k}$ and the $\mathrm{OH}$ radical concentration of the different atmospheric scenarios (Supplement, Eq. 3).

\subsubsection{Hydrophilic amino acids}

The hydrophilic amino acids (Asp, Glu, GABA) comprised a significant fraction in the ULW and the SML, as well as in the (submicron) aerosol particles and in cloud water (Fig. 4a-d). They were not detected in the supermicron aerosol particles. A conspicuous finding is the high concentration of GABA, which is present exclusively in the submicron aerosol particles (B1 and B2: $0.05-0.42 \mu \mathrm{m}$ ) at the CVAO. Despite the relatively high LOQ of GABA in seawater (Table S1), a major abundance of GABA in seawater 
would be detectable. GABA is a metabolic product of the microbiological decarboxylation of Glu, which has been detected in all marine compartments. Active microbial enzymes on nascent sea spray aerosol have recently been reported by Malfatti et al. (2019). The abundance of GABA in the submicron aerosol particles suggests that either GABA could have been produced by the microbiological decarboxylation of Glu by present (marine) microorganisms in the aerosol particles or that GABA was transferred from the seawater to the atmosphere. However, GABA could not be found in seawater (ULW and SML), and this is not related to the sensitivity of the analytical method. Hence, a very enhanced oceanic transfer of GABA would be needed to explain this finding. Such an enhanced transfer was, however, not observed for the other hydrophilic amino acids (Glu and Asp), and their percentage composition was not strongly different regarding seawater and submicron aerosol particles at the CVAO. Unless the oceanic transfer of GABA is very different compared to other hydrophilic amino acids, this pathway does not explain the high abundance of GABA in the submicron aerosol particles at the CVAO.

Together with the facts that GABA is a known indicator for the microbiological decomposition of OM (Dauwe et al., 1999; Engel et al., 2018) and microorganisms are known to be present in marine aerosol particles even in the submicron size range (Rastelli et al., 2017), the formation of GABA in the aerosol particles might be related to an in situ formation. Interestingly, GABA was not detected in cloud water samples, although bacteria were found during the campaign in cloud water (van Pinxteren et al., 2020) whose presence has been reported in the literature (Jardine, 2009; Vaitilingom et al., 2013; Jiaxian et al., 2019). It remains speculative whether GABA was degraded in cloud water despite its rather long lifetime (remote cloud case: $28.8 \mathrm{~h}$; Table S13) or whether it was not produced by the bacteria in cloud water. Asp has been detected in all marine compartments and showed high cloud water concentrations. Correlations between Asp with diatoms and zooplankton have been reported for the marine environment (Hammer and Kattner, 1986). Hence, the occurrence of Asp in the marine environment can be attributed to a biogenic origin, while the high concentrations of Asp in cloud water (Figs. 3 and 4d) might be related to an oceanic source. In the Antarctic, Barbaro et al. (2015) attributed the hydrophilic amino acid fraction mainly to locally produced aerosol particles. According to the biogenic sources of the hydrophilic acids and their characteristics observed here, a local marine source for Asp and Glu, together with the biogenic formation of GABA in the aerosol particles in the Cabo Verde islands, could be prevalent.

\subsubsection{Neutral and hydrophobic amino acids}

Neutral amino acids were generally the amino acid group with the highest concentration in all investigated marine compartments, accounting for more than $50 \%$ of the FAA total (Fig. 4a-d). Ser and Gly were the dominant representatives of this group. It is remarkable that especially the aerosol particles in the larger size range (e.g., supermicron aerosol particles: B4, B5) at both sampling stations are less complex in amino acid composition and almost exclusively dominated by Gly, followed by Ser and Ala (Fig. 4b, c). Gly is discussed in the literature as a photochemical degradation product of other existing amino acids, and this comparatively more stable amino acid (Gly) thus becomes a major component of the FAA composition (Barbaro et al., 2015). Compared to other amino acids, Gly and Ser have a very low atmospheric reactivity (McGregor and Anastasio, 2001) and therefore a higher mean lifetime $\tau$ (Gly: $0.48 \mathrm{~h}$; Ser: $0.24 \mathrm{~h}$; remote aerosol case; Table S13). Due to its atmospheric stability, Gly is proposed as an indicator for long-range transport (Barbaro et al., 2015, and references therein) and has a very low atmospheric reactivity (McGregor and Anastasio, 2001). However, our results clearly show that Gly and Ser are also present in seawater to a high extent, likely resulting from the siliceous exoskeleton of diatom cell walls (e.g., Hecky et al., 1973). Hence, besides long-range transport, a transfer from the ocean via bubble bursting might be an additional likely source of the stable, long-lived FAAs in the atmosphere. The neutral amino acid Pro has been reported to be of biogenic origin in the marine environment and was detected in seawater (Fig. 4a), in submicron aerosol particles at the CVAO (Fig. 4b) and in cloud water (Fig. 4d). Fischer et al. (2004) demonstrated that Pro can be used to identify the presence of algal spores in aerosol particles and might thus be used as a tracer for an oceanic source. The presence of Pro in all marine compartments suggests a transfer from the ocean into the atmosphere up to cloud level. This is supported by the comparatively low atmospheric reactivity of Pro (remote aerosol case: $0.24 \mathrm{~h}$; Table S13). Finally, the hydrophobic FAAs Ile, Leu and Thr were found in all marine compartments in low concentrations. They are classified as relatively reactive amino acids and their abundance has been attributed to local or semi-local sources consequently (e.g., Mashayekhy Rad et al., 2019). Their low but constant abundance in all marine matrices again indicates a bubblebursting transfer.

\subsubsection{Aromatic amino acids}

Aromatic FAAs like Phe and Tyr were present in seawater but not in the aerosol particles nor in cloud water samples. It could be assumed that either these aromatic FAAs were not transferred from the ocean into the atmosphere, they reacted already after their transfer due to chemical transformation reactions, or they were not detected because of their low atmospheric concentration. The mean lifetimes $\tau$ of Phe $(0.014 \mathrm{~h})$ and $\operatorname{Tyr}(0.007 \mathrm{~h})$ (Table S13) showed that both FAAs had a comparatively high atmospheric reactivity $(\tau<1 \mathrm{~min})$ in remote aerosol case conditions. Hence, a rapid chemical reaction of these compounds is most likely. Moreover, previ- 
ous studies reported low atmospheric concentrations of Tyr and Phe in aerosol particles. Barbaro et al. (2011) found Phe $\left(0.5 \mathrm{ng} \mathrm{m}^{-3}\right)$ and Tyr $\left(0.3 \mathrm{ng} \mathrm{m}^{-3}\right)$ with a contribution of $<1 \%$ to $\sum$ FAA ( $\sum$ FAA: $42.5 \mathrm{ng} \mathrm{m}^{-3}$ ) on TSP samples in the urban background (Venice, Italy). In our study at the CVAO, the mean value of $\sum$ FAA in $\mathrm{PM}_{10}$ aerosol particles was $3.8 \mathrm{ng} \mathrm{m}^{-3}$ (Sect. 3.2). Assuming that Phe and Tyr were contributing a very small fraction to $\sum$ FAA, as reported in Barbaro et al. (2011), their concentrations would be below the detection limit and would thus probably not be detected. It can be concluded that either the aromatic FAAs could not be quantified in aerosol particles due to the sensitivity of the analytical method used here or they could react very quickly in the atmosphere and would therefore not be detected.

\subsubsection{Transfer of amino acids from the ocean into the atmosphere}

A high similarity regarding the FAA species within the different marine compartments could be observed, although some differences could also be identified (e.g., GABA). Together with the high concentration of ocean-derived compounds $\left(\mathrm{Na}^{+}, \mathrm{MSA}\right)$ in the aerosol particles and cloud water, this indicates a coupling between the FAAs in the ocean and the atmosphere. A quantitative metric for comparing compounds in the ocean and in the atmosphere is the $\mathrm{EF}_{\text {aer }}$ (Eq. 2). The concept is mainly applied to closed systems (e.g., Quinn et al., 2015; Rastelli et al., 2017) because FAA formation or degradation pathways in the aerosol particles including biological or photochemical atmospheric reactions, and possible transport from sources other than marine, are excluded in this parameter. However, for comparison purposes, it might be useful to calculate the $\mathrm{EF}_{\mathrm{aer}}$ also from open systems, as done, e.g., by Russell et al. (2010) or van Pinxteren et al. (2017). The averaged $\mathrm{EF}_{\mathrm{aer}}$ of $\sum \mathrm{FAA}$ in the individual Berner stages of the case study at the CVAO based on SML and ULW concentrations are shown in Fig. 5.

The $\mathrm{EF}_{\text {aer }}$ of $\sum F A A$, based on SML, were in the supermicron size range $\left(1 \times 10^{1}, \mathrm{~B} 5,1 \times 10^{1}, \mathrm{~B} 4\right)$ and several orders of magnitude smaller than in the submicron range $\left(4 \times 10^{2}\right.$, B3, $\left.2 \times 10^{4}, \mathrm{~B} 2,5 \times 10^{3}, \mathrm{~B} 1\right)$. Furthermore, the calculated $\mathrm{EF}_{\text {aer }}$, based on ULW, was up to 1 order of magnitude higher in the aerosol particles than the $\mathrm{EF}_{\mathrm{aer}}$, based on the SML. This is due to the different FAA concentrations in seawater (Sect. 3.1) as the sodium values were very similar at $12.45 \mathrm{~g} \mathrm{~L}^{-1}$ in the ULW and $12.53 \mathrm{~g} \mathrm{~L}^{-1}$ in the SML. It was shown by van Pinxteren et al. (2017) that the $\mathrm{EF}_{\mathrm{aer}}$ of the WSOC in the submicron marine ambient aerosol particles at Cabo Verde ranged between $10^{3}$ and $10^{5}$. The averaged $\mathrm{EF}_{\text {aer }}$ of the WSOC during our campaign was between $2 \times 10^{3}$ and $1 \times 10^{4}$ in the submicron range, between $3 \times 10^{2}$ and $4 \times 10^{2}$ in the supermicron range (Table S14), and in good agreement with van Pinxteren et al. (2017). Comparing the $\mathrm{EF}_{\text {aer }}$ of $\sum$ FAA $\left(1 \times 10^{1}-2 \times 10^{4}\right)$ with the $\mathrm{EF}_{\text {aer }}$ of WSOC $\left(1 \times 10^{1}-\right.$ $\left.2 \times 10^{4}\right)$ in the submicron range, both $\mathrm{EF}_{\mathrm{aer}}$ values are on the same order of magnitude. Moreover, similar percentages of $\sum$ FAA were observed for the DOC in the SML (up to $7.6 \%$ ) (Sect. 3.1) and for the WSOC in submicron aerosol particles (up to $5.3 \%$ ) (Sect. 3.2).

Previous studies have shown that OM ejected into the atmosphere during bubble bursting results in the formation of sea spray aerosol particles containing OM similar to SML (Russell et al., 2010; Cunliffe et al., 2013, and references therein). Especially the film droplets have been reported to be enriched in $\mathrm{OM}$ and are suggested to transfer OM from the SML into submicron aerosol particles (Wilson et al., 2015). The supermicron aerosol particles tend to form from the larger jet droplets and thus represent the ULW composition (Blanchard, 1975; Wilson et al., 2015). We cannot derive mechanistic transfer characterizations from the ambient measurements performed here. Nevertheless, the constant FAA enrichment in the SML, together with the strong FAA enrichment in the submicron aerosol particles, strongly suggests that film droplets form the submicron particles. However, Wang et al. (2017) showed that jet drops (which transfer OM from the ULW) also have the potential to contribute significantly to the formation of submicron sea spray aerosol particles; so jet droplets can also contribute to FAA formation.

Applying the concept of the enrichment factor to cloud water and calculating the $\mathrm{EF}_{\mathrm{CW}}$ (Eq. 2), $\mathrm{EF}_{\mathrm{CW}\left(\sum \mathrm{FAA}\right)}=4 \times 10^{3}$ (based on SML) and $1 \times 10^{4}$ (based on ULW) could be determined. As mentioned in Sect. 3.3, several atmospheric processing (aging), oceanic transfer and biogenic-driven processes might contribute to this high enrichment and need to be addressed in future studies. The high FAA concentrations and enrichments might have implications for OM processing through clouds and are worth further studying.

\section{Conclusion and outlook}

Concerted measurements, i.e., simultaneous measurements of seawater, size-segregated aerosol particles and cloud water samples during the MarParCloud campaign at the CVAO and MV stations, allowed us to investigate FAAs on a molecular level, which are important contributors to marine OM. The similarities between the FAA composition in the seawater (SML) and in the submicron aerosol particle samples, as described in Sect. 3.4, indicated that a certain FAA contribution, in particular the hydrophilic amino acids Asp and Glu in the submicron aerosol particles at the CVAO, was probably caused by sea spray and might be transferred up to cloud level. The neutral and hydrophobic amino acids were also present in all marine compartments, suggesting some interconnections. Stable amino acids like Gly are often reported as long-range tracers, but their abundance in seawater and marine air masses prevailing during the sampling period suggests an (additional) oceanic source. The oceanic link is supported by a high atmospheric concentration of ocean-derived 

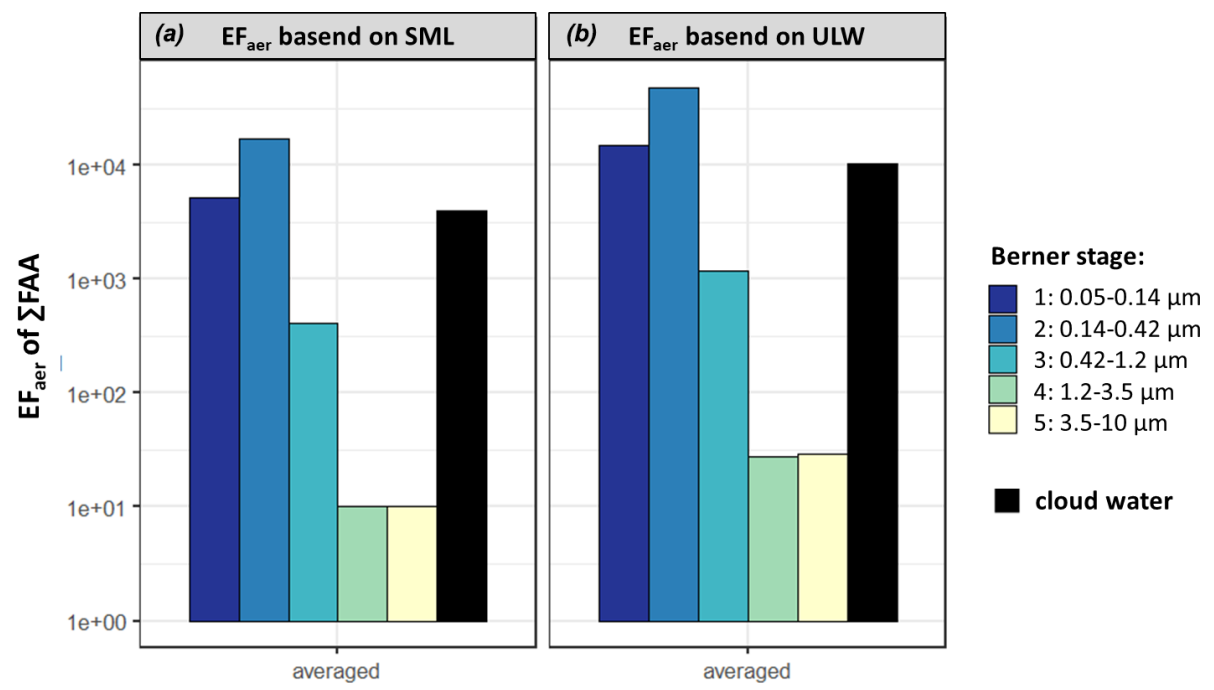

Figure 5. The averaged aerosol enrichment factor $\left(\mathrm{EF}_{\mathrm{aer}}\right)$ of $\sum \mathrm{FAA}$ in the size-segregated aerosol particle samples $(\mathrm{Berner}$ stage 1-5) at the CVAO and the cloud water enrichment factor ( $\mathrm{EF}_{\mathrm{CW}}$ in black) based on SML (a) and on ULW (b) calculation (Eq. 2).

compounds (sodium, MSA), a high fractional residence time of the air masses above water and a low-to-medium impact of other non-marine sources (based, for example, on the mass concentration of trace metals). In addition, some indications for the biological production of amino acids in the aerosol particles (GABA) were observed. Aromatic amino acids are either not transferred from the ocean into the atmosphere or they react very quickly; in any case, they are present only in small concentrations close to the LOQ. By distinguishing between submicron and supermicron aerosol particles, differences in the chemical composition of these aerosol particle size classes could be identified, which shows a much higher complexity of the FAA composition in the submicron aerosol particles. FAAs were present in the size range for aerosol particles associated with CCN activity and cloud water and might be connected to $\mathrm{CCN}$ activity due to their hygroscopicity and soluble character, but this effect was not investigated here and should be examined in future studies. In a simplified approach, considering only a possible transfer from the ocean into the aerosol particles and cloud water (neglecting, for example, atmospheric processing), the aerosol enrichment factor was calculated. A high FAA enrichment in the submicron aerosol particles $\left(\mathrm{EF}_{\mathrm{aer}\left(\sum \mathrm{FAA}\right)}: 2 \times 10^{1}\right.$ $6 \times 10^{3}$ ) and a medium enrichment in supermicron aerosol particles $\left(\mathrm{EF}_{\mathrm{aer}\left(\sum \mathrm{FAA}\right)}: 1 \times 10^{1}-3 \times 10^{1}\right)$ were observed. Applying the same concept to cloud water, an enrichment of $4 \times 10^{3}-1 \times 10^{4}$ was obtained.

The high FAA concentrations (11.2-489.9 $\mathrm{ng} \mathrm{m}^{-3}$ ) and enrichments in cloud water were reported here for the first time. Their composition, together with the high concentrations of inorganic marine tracers (sodium, MSA), indicate at least to some extent an oceanic transfer and biogenic formation that remain subject to future work. Altogether, the varying composition of FAAs in the different matrices shows that their abundance and their enrichments in the SML and their atmospheric transfer are not determined by single environmental drivers (e.g., wind speed) and/or simple physicochemical parameters (e.g., surface activity). The oceanatmosphere transfer of FAAs is influenced by biotic and abiotic formation and degradation processes. Further studies are required to unravel their drivers and understand their complex composition that, finally, have to be considered in OM transfer models. To the best of our knowledge, this study was the first that simultaneously analyzed the FAAs in all marine compartments - seawater including the ULW and the SML, size-segregated aerosol particles, and cloud water - in such detail to obtain indications of their sources and interconnections.

Data availability. The data are available through the World Data Center PANGAEA under the following link: https://doi.pangaea.de/ 10.1594/PANGAEA.914220 (Triesch et al., 2020).

Supplement. The supplement related to this article is available online at: https://doi.org/10.5194/acp-21-163-2021-supplement.

Author contributions. NT wrote the paper with contributions from $\mathrm{MvP}, \mathrm{HH}$ and AE. NT and MvP performed the field sampling as part of the MarParCloud campaign team and NT the chemical measurements of amino acids. The chemical data evaluation was done by $\mathrm{NT}$ in consultation with $\mathrm{HH}$ and $\mathrm{MvP}$ and with the researcher mentioned in the Acknowledgements. All authors discussed the results and further analysis after the campaign. All coauthors proofread and commented on the paper. 
Competing interests. The authors declare that they have no conflict of interest.

Special issue statement. This article is part of the special issue "Marine organic matter: from biological production in the ocean to organic aerosol particles and marine clouds (ACP/OS inter-journal SI)". It is not associated with a conference.

Acknowledgements. The authors thank Susanne Fuchs, Anett Dietze, Sontje Krupka, René Rabe and Anke Rödger for providing additional data and filter samples and all MarParCloud and MARSU project partners, especially Malena Manzi, for good cooperation and support. We additionally thank Khanneh Wadinga Fomba and his support in the context of mineral dust and cloud water analytics, Thomas Schaefer regarding the kinetic analysis, and Tobias Spranger concerning data visualization. We further acknowledge the professional support provided by the Ocean Science Centre Mindelo (OSCM) and the Instituto do Mar (IMar).

Financial support. This research has been supported by the Leibniz Association SAW for the project "marine biological production, organic aerosol particles and marine clouds: a process chain (MarPar-Cloud)" (grant no. SAW-2016-TROPOS-2) and within the Research and Innovation Staff Exchange EU project MARSU (grant no. 69089).

Review statement. This paper was edited by Nikolaos Mihalopoulos and reviewed by Matthew Pendergraft and three anonymous referees.

\section{References}

Aller, J. Y., Kuznetsova, M. R., Jahns, C. J., and Kemp, P. F.: The sea surface microlayer as a source of viral and bacterial enrichment in marine aerosols, J. Aerosol Sci., 36, 801-812, https://doi.org/10.1016/j.jaerosci.2004.10.012, 2005.

Antia, N. J., Harrison, P., and Oliveira, L.: The Role of Dissolved Organic Nitrogen in Phytoplankton Nutrition, Cell Biol. Ecol., 30, 1-89, https://doi.org/10.2216/i0031-8884-30-1-1.1, 1991.

Barbaro, E., Zangrando, R., Moret, I., Barbante, C., Cescon, P., and Gambaro, A.: Free amino acids in atmospheric particulate matter of Venice, Italy, Atmos. Environ., 45, 5050-5057, https://doi.org/10.1016/j.atmosenv.2011.01.068, 2011.

Barbaro, E., Zangrando, R., Vecchiato, M., Piazza, R., Cairns, W. R. L., Capodaglio, G., Barbante, C., and Gambaro, A.: Free amino acids in Antarctic aerosol: potential markers for the evolution and fate of marine aerosol, Atmos. Chem. Phys., 15, 5457-5469, https://doi.org/10.5194/acp-15-5457-2015, 2015.

Bianco, A., Voyard, G., Deguillaume, L., Mailhot, G., and Brigante, M.: Improving the characterization of dissolved organic carbon in cloud water: Amino acids and their impact on the oxidant capacity, Sci. Rep., 6, 7, https://doi.org/10.1038/srep37420, 2016.
Blanchard, D. C.: Bubble Scavenging and the Water-to-Air Transfer of Organic Material in the Sea, in: Applied Chemistry at Protein Interfaces, Advances in Chemistry, 145, American Chemical Society, 360-387, 1975.

Bradford, M. M.: Rapid and sensitive method for quantitation of microgram quantities of protein utilizing principle of protein-dye binding, Anal. Biochem., 72, 248-254, https://doi.org/10.1006/abio.1976.9999, 1976.

Carpenter, L. J., Fleming, Z. L., Read, K. A., Lee, J. D., Moller, S. J., Hopkins, J. R., Purvis, R. M., Lewis, A. C., Muller, K., Heinold, B., Herrmann, H., Fomba, K. W., van Pinxteren, D., Muller, C., Tegen, I., Wiedensohler, A., Muller, T., Niedermeier, N., Achterberg, E. P., Patey, M. D., Kozlova, E. A., Heimann, M., Heard, D. E., Plane, J. M. C., Mahajan, A., Oetjen, H., Ingham, T., Stone, D., Whalley, L. K., Evans, M. J., Pilling, M. J., Leigh, R. J., Monks, P. S., Karunaharan, A., Vaughan, S., Arnold, S. R., Tschritter, J., Pohler, D., Friess, U., Holla, R., Mendes, L. M., Lopez, H., Faria, B., Manning, A. J., and Wallace, D. W. R.: Seasonal characteristics of tropical marine boundary layer air measured at the Cape Verde Atmospheric Observatory, J. Atmos. Chem., 67, 87-140, https://doi.org/10.1007/s10874-011-9206-1, 2010.

Chan, M. N., Choi, M. Y., Ng, N. L., and Chan, C. K.: Hygroscopicity of water-soluble organic compounds in atmospheric aerosols: amino acids and biomass burning derived organic species, Environ. Sci. Technol., 39, 1555-1562, https://doi.org/10.1021/es0495841, 2005.

Cunliffe, M., Engel, A., Frka, S., Gašparović, B., Guitart, C., Murrell, J. C., Salter, M., Stolle, C., UpstillGoddard, R., and Wurl, O.: Sea surface microlayers: A unified physicochemical and biological perspective of the air - ocean interface, Prog. Oceanogr., 109, 104-116, https://doi.org/10.1016/j.pocean.2012.08.004, 2013.

Cunliffe, M. and Wurl, O.: Guide to best practices to study the ocean's surface, Plymouth, UK, Marine Biological Association of the United Kingdom for SCOR, 118 pp., 2014.

Dauwe, B., Middelburg, J. J., Herman, P. M. J., and Heip, C. H. R.: Linking diagenetic alteration of amino acids and bulk organic matter reactivity, Limnol. Oceanogr., 44, 1809-1814, https://doi.org/10.4319/lo.1999.44.7.1809, 1999.

Demoz, B. B., Collett, J. L., and Daube, B. C.: On the Caltech Active Strand Cloudwater Collectors, Atmos. Res., 41, 47-62, https://doi.org/10.1016/0169-8095(95)00044-5, 1996.

Engel, A. and Galgani, L.: The organic sea-surface microlayer in the upwelling region off the coast of Peru and potential implications for air-sea exchange processes, Biogeosciences, 13, 989-1007, https://doi.org/10.5194/bg-13-989-2016, 2016.

Engel, A., Bange, H. W., Cunliffe, M., Burrows, S. M., Friedrichs, G., Galgani, L., Herrmann, H., Hertkorn, N., Johnson, M., Liss, P. S., Quinn, P. K., Schartau, M., Soloviev, A., Stolle, C., Upstill-Goddard, R. C., van Pinxteren, M., and Zäncker, B.: The Ocean's Vital Skin: Toward an Integrated Understanding of the Sea Surface Microlayer, Front. Mar. Sci., 4, 165, https://doi.org/10.3389/fmars.2017.00165, 2017.

Engel, A., Sperling, M., Sun, C., Grosse, J., and Friedrichs, G.: Organic Matter in the Surface Microlayer: Insights From a Wind Wave Channel Experiment, Front. Mar. Sci., 5, 182, https://doi.org/10.3389/fmars.2018.00182, 2018. 
Feltracco, M., Barbaro, E., Kirchgeorg, T., Spolaor, A., Turetta, C., Zangrando, R., Barbante, C., and Gambaro, A.: Free and combined L- and D-amino acids in Arctic aerosol, Chemosphere, 220, 412-421, https://doi.org/10.1016/j.chemosphere.2018.12.147, 2019.

Fischer, M., Cox, J., Davis, D. J., Wagner, A., Taylor, R., Huerta, A. J., and Money, N. P.: New information on the mechanism of forcible ascospore discharge from Ascobolus immersus, Fungal Genet. Biol., 41, 698-707, https://doi.org/10.1016/j.fgb.2004.03.005, 2004.

Fomba, K. W., Müller, K., van Pinxteren, D., and Herrmann, H.: Aerosol size-resolved trace metal composition in remote northern tropical Atlantic marine environment: case study Cape Verde islands, Atmos. Chem. Phys., 13, 4801-4814, https://doi.org/10.5194/acp-13-4801-2013, 2013.

Fomba, K. W., Müller, K., van Pinxteren, D., Poulain, L., van Pinxteren, M., and Herrmann, H.: Long-term chemical characterization of tropical and marine aerosols at the Cape Verde Atmospheric Observatory (CVAO) from 2007 to 2011, Atmos. Chem. Phys., 14, 8883-8904, https://doi.org/10.5194/acp-148883-2014, 2014.

Fomba, K. W., van Pinxteren, D., Müller, K., Iinuma, Y., Lee, T., Collett Jr., J. L., and Herrmann, H.: Trace metal characterization of aerosol particles and cloud water during HCCT 2010, Atmos. Chem. Phys., 15, 8751-8765, https://doi.org/10.5194/acp15-8751-2015, 2015.

Gantt, B., Meskhidze, N., Facchini, M. C., Rinaldi, M., Ceburnis, D., and O'Dowd, C. D.: Wind speed dependent size-resolved parameterization for the organic mass fraction of sea spray aerosol, Atmos. Chem. Phys., 11, 8777-8790, https://doi.org/10.5194/acp-11-8777-2011, 2011.

Gioda, A., Mayol-Bracero, O. L., Morales-García, F., Collett, J., Decesari, S., Emblico, L., Facchini, M. C., Morales-De Jesús, R. J., Mertes, S., Borrmann, S., Walter, S., and Schneider, J.: Chemical Composition of Cloud Water in the Puerto Rican Tropical Trade Wind Cumuli, Water Air Soil Pollut., 200, 3-14, https://doi.org/10.1007/s11270-008-9888-4, 2009.

Gong, X., Wex, H., Voigtländer, J., Fomba, K. W., Weinhold, K., van Pinxteren, M., Henning, S., Müller, T., Herrmann, H., and Stratmann, F.: Characterization of aerosol particles at Cabo Verde close to sea level and at the cloud level - Part 1: Particle number size distribution, cloud condensation nuclei and their origins, Atmos. Chem. Phys., 20, 1431-1449, https://doi.org/10.5194/acp-20-1431-2020, 2020.

Gutiérrez-Castillo, M. E., Olivos-Ortiz, M., De Vizcaya-Ruiz, A., and Cebrián, M. E.: Chemical characterization of extractable water soluble matter associated with $\mathrm{PM}_{10}$ from Mexico City during 2000, Chemosphere, 61, 701-710, https://doi.org/10.1016/j.chemosphere.2005.03.063, 2005.

Hammer, K. D. and Kattner, G.: Dissolved free amino acids in the marine environment: a carbon to nitrogen ratio shift during diatom blooms, Mar. Ecol.-Prog. Ser., 31, 35-45, 1986.

Hecky, R. E., Mopper, K., Kilham, P., and Degens, E. T.: The amino acid and sugar composition of diatom cell-walls, Mar. Biol., 19, 323-331, https://doi.org/10.1007/BF00348902, 1973.

Jaber, S., Joly, M., Brissy, M., Leremboure, M., Khaled, A., Ervens, B., and Delort, A.-M.: Biotic and abiotic transformation of amino acids in cloud water: Experimental studies and atmospheric im- plications, Biogeosciences Discuss., https://doi.org/10.5194/bg2020-250, in review, 2020.

Jardine, B.: Between the Beagle and the barnacle: Darwin's microscopy, 1837-1854, Stud. Hist. Philos. Sci., 40, 382-395, https://doi.org/10.1016/j.shpsa.2009.10.007, 2009.

Jiaxian, P., Shumin, Z., Kai, X., Junyang, Z., Chuanhe, Y., Senlin, L., Wei, Z., Yuzhen, F., Yuxiang, Y., Xinhui, B., Guohua, Z., and Qingyue, W.: Diversity of bacteria in cloud water collected at a National Atmospheric Monitoring Station in Southern China, Atmos. Res., 218, 176-182, https://doi.org/10.1016/j.atmosres.2018.12.004, 2019.

Kanji, Z. A., Ladino, L. A., Wex, H., Boose, Y., BurkertKohn, M., Cziczo, D. J., and Krämer, M.: Overview of Ice Nucleating Particles, Meteor. Mon., 58, 1.1-1.33, https://doi.org/10.1175/amsmonographs-d-16-0006.1, 2017.

Kristensson, A., Rosenørn, T., and Bilde, M.: Cloud Droplet Activation of Amino Acid Aerosol Particles, J. Phys. Chem. A, 114, 379-386, https://doi.org/10.1021/jp9055329, 2010.

Kuznetsova, M. and Lee, C.: Dissolved free and combined amino acids in nearshore seawater, sea surface microlayers and foams: Influence of extracellular hydrolysis, Aquat. Sci., 64, 252-268, https://doi.org/10.1007/s00027-002-8070-0, 2002.

Kuznetsova, M., Lee, C., Aller, J., and Frew, N.: Enrichment of amino acids in the sea surface microlayer at coastal and open ocean sites in the North Atlantic Ocean, Limnol. Oceanogr., 49, 1605-1619, https://doi.org/10.4319/lo.2004.49.5.1605, 2004.

Kuznetsova, M., Lee, C., and Aller, J.: Characterization of the proteinaceous matter in marine aerosols, Mar. Chem., 96, 359-377, https://doi.org/10.1016/j.marchem.2005.03.007, 2005.

Kyte, J. and Doolittle, R. F.: A simple method for displaying the hydropathic character of a protein, J. Mol. Biol., 157, 105-132, https://doi.org/10.1016/0022-2836(82)90515-0, 1982.

Lesworth, T., Baker, A. R., and Jickells, T.: Aerosol organic nitrogen over the remote Atlantic Ocean, Atmos. Environ., 44, 18871893, https://doi.org/10.1016/j.atmosenv.2010.02.021, 2010.

Longhurst, A. R.: Chapter 9 - THE ATLANTIC OCEAN, in: Ecological Geography of the Sea (Second Edition), edited by: Longhurst, A. R., Academic Press, Burlington, 131-273, 2007.

Malfatti, F., Lee, C., Tinta, T., Pendergraft, M. A., Celussi, M., Zhou, Y., Sultana, C. M., Rotter, A., Axson, J. L., Collins, D. B., Santander, M. V., Anides Morales, A. L., Aluwihare, L. I., Riemer, N., Grassian, V. H., Azam, F., and Prather, K. A.: Detection of Active Microbial Enzymes in Nascent Sea Spray Aerosol: Implications for Atmospheric Chemistry and Climate, Environ. Sci. Technol. Lett., 6, 171-177, https://doi.org/10.1021/acs.estlett.8b00699, 2019.

Mandalakis, M., Apostolaki, M., Tziaras, T., Polymenakou, P., and Stephanou, E. G.: Free and combined amino acids in marine background atmospheric aerosols over the Eastern Mediterranean, Atmos. Environ., 45, 1003-1009, https://doi.org/10.1016/j.atmosenv.2010.10.046, 2011.

Mashayekhy Rad, F., Zurita, J., Gilles, P., Rutgeerts, L. A. J., Nilsson, U., Ilag, L. L., and Leck, C.: Measurements of Atmospheric Proteinaceous Aerosol in the Arctic Using a Selective UHPLC/ESI-MS/MS Strategy, J. Am. Soc. Mass. Spectrom., 30, 161-173, https://doi.org/10.1007/s13361-018-2009-8, 2019.

Matos, J. T. V., Duarte, R., and Duarte, A. C.: Challenges in the identification and characterization of free amino acids and proteinaceous compounds in atmospheric aerosols: 
A critical review, Trac-Trends Anal. Chem., 75, 97-107, https://doi.org/10.1016/j.trac.2015.08.004, 2016.

Matsumoto, K. and Uematsu, M.: Free amino acids in marine aerosols over the western North Pacific Ocean, Atmos. Environ., 39, 2163-2170, https://doi.org/10.1016/j.atmosenv.2004.12.022, 2005.

McGregor, K. G. and Anastasio, C.: Chemistry of fog waters in California's Central Valley: 2. Photochemical transformations of amino acids and alkyl amines, Atmos. Environ., 35, 1091-1104, https://doi.org/10.1016/S1352-2310(00)00282-X, 2001.

Milne, P. J. and Zika, R. G.: Amino acid nitrogen in atmospheric aerosols: Occurrence, sources and photochemical modification, J. Atmos. Chem., 16, 361-398, https://doi.org/10.1007/bf01032631, 1993.

Müller, K., Lehmann, S., van Pinxteren, D., Gnauk, T., Niedermeier, N., Wiedensohler, A., and Herrmann, H.: Particle characterization at the Cape Verde atmospheric observatory during the 2007 RHaMBLe intensive, Atmos. Chem. Phys., 10, 2709-2721, https://doi.org/10.5194/acp-10-2709-2010, 2010.

Niedermeier, N., Held, A., Müller, T., Heinold, B., Schepanski, K., Tegen, I., Kandler, K., Ebert, M., Weinbruch, S., Read, K., Lee, J., Fomba, K. W., Müller, K., Herrmann, H., and Wiedensohler, A.: Mass deposition fluxes of Saharan mineral dust to the tropical northeast Atlantic Ocean: an intercomparison of methods, Atmos. Chem. Phys., 14, 2245-2266, https://doi.org/10.5194/acp14-2245-2014, 2014.

Pandey, R., Usui, K., Livingstone, R. A., Fischer, S. A., Pfaendtner, J., Backus, E. H. G., Nagata, Y., Fröhlich-Nowoisky, J., Schmüser, L., Mauri, S., Scheel, J. F., Knopf, D. A., Pöschl, U., Bonn, M., and Weidner, T.: Ice-nucleating bacteria control the order and dynamics of interfacial water, Sci. Adv., 2, e1501630, https://doi.org/10.1126/sciadv.1501630, 2016.

Pommié, C., Levadoux, S., Sabatier, R., Lefranc, G., and Lefranc, M.-P.: IMGT standardized criteria for statistical analysis of immunoglobulin V-REGION amino acid properties, J. Mol. Recognit., 17, 17-32, https://doi.org/10.1002/jmr.647, 2004.

Pósfai, M., Li, J., Anderson, J. R., and Buseck, P. R.: Aerosol bacteria over the Southern Ocean during ACE-1, Atmos. Res., 66, 231-240, https://doi.org/10.1016/S0169-8095(03)00039-5, 2003.

Quinn, P. K., Collins, D. B., Grassian, V. H., Prather, K. A., and Bates, T. S.: Chemistry and Related Properties of Freshly Emitted Sea Spray Aerosol, Chem. Rev., 115, 4383-4399, https://doi.org/10.1021/cr500713g, 2015.

Rastelli, E., Corinaldesi, C., Dell' Anno, A., Lo Martire, M., Greco, S., Cristina Facchini, M., Rinaldi, M., O’Dowd, C., Ceburnis, D., and Danovaro, R.: Transfer of labile organic matter and microbes from the ocean surface to the marine aerosol: an experimental approach, Sci. Rep., 7, 11475, https://doi.org/10.1038/s41598-01710563-z, 2017.

Reinthaler, T., Sintes, E., and Herndl, G. J.: Dissolved organic matter and bacterial production and respiration in the sea-surface microlayer of the open Atlantic and the western Mediterranean Sea, Limnol. Oceanogr., 53, 122-136, https://doi.org/10.4319/lo.2008.53.1.0122, 2008.

Rinaldi, M., Fuzzi, S., Decesari, S., Marullo, S., Santoleri, R., Provenzale, A., von Hardenberg, J., Ceburnis, D., Vaishya, A., O'Dowd, C. D., and Facchini, M. C.: Is chlorophyll-a the best surrogate for organic matter enrichment in submicron primary marine aerosol?, J. Geophys. Res.-Atmos., 118, 4964-4973, https://doi.org/10.1002/jgrd.50417, 2013.

Russell, L. M., Hawkins, L. N., Frossard, A. A., Quinn, P. K., and Bates, T. S.: Carbohydrate-like composition of submicron atmospheric particles and their production from ocean bubble bursting, P. Natl. Acad. Sci. USA, 107, 6652-6657, https://doi.org/10.1073/pnas.0908905107, 2010.

Scalabrin, E., Zangrando, R., Barbaro, E., Kehrwald, N. M., Gabrieli, J., Barbante, C., and Gambaro, A.: Amino acids in Arctic aerosols, Atmos. Chem. Phys., 12, 10453-10463, https://doi.org/10.5194/acp-12-10453-2012, 2012.

Szyrmer, W. and Zawadzki, I.: Biogenic and anthropogenic sources of ice-forming nuclei: A review, B. Am. Meteorol. Soc., 78, 209-228, https://doi.org/10.1175/15200477(1997)078<0209:baasoi>2.0.co;2, 1997.

Triesch, N., van Pinxteren, M., Engel, A., and Herrmann, H.: Simultaneous measurements of free amino acids in seawater, size-segregated aerosol particle and cloud water samples at the Cape Verde Atmospheric Observatory, PANGAEA, https:// doi.pangaea.de/10.1594/PANGAEA.914220 (dataset in review), 2020.

Vaïtilingom, M., Deguillaume, L., Vinatier, V., Sancelme, M., Amato, P., Chaumerliac, N., and Delort, A.-M.: Potential impact of microbial activity on the oxidant capacity and organic carbon budget in clouds, P. Natl. Acad. Sci., 110, 559-564, https://doi.org/10.1073/pnas.1205743110, 2013.

van Pinxteren, D., Bruegemann, E., Gnauk, T., Mueller, K., Thiel, C., and Herrmann, H.: A GIS based approach to back trajectory analysis for the source apportionment of aerosol constituents and its first application, J. Atmos. Chem., 67, 1, https://doi.org/10.1007/s10874-011-9199-9, 2010.

van Pinxteren, M., Muller, C., Iinuma, Y., Stolle, C., and Herrmann, H.: Chemical Characterization of Dissolved Organic Compounds from Coastal Sea Surface Micro layers (Baltic Sea, Germany), Environ. Sci. Technol., 46, 10455-10462, https://doi.org/10.1021/es204492b, 2012.

van Pinxteren, M., Fiedler, B., van Pinxteren, D., Iinuma, Y., Körtzinger, A., and Herrmann, H.: Chemical characterization of sub-micrometer aerosol particles in the tropical Atlantic Ocean: marine and biomass burning influences, J. Atmos. Chem., 72, 105-125, https://doi.org/10.1007/s10874-015-9307-3, 2015.

van Pinxteren, M., Barthel, S., Fomba, K. W., Muller, K., von Tumpling, W., and Herrmann, H.: The influence of environmental drivers on the enrichment of organic carbon in the sea surface microlayer and in submicron aerosol particles - measurements from the Atlantic Ocean, Elementa-Sci. Anthrop., 5, 21, https://doi.org/10.1525/elementa.225, 2017.

van Pinxteren, M., Fomba, K. W., van Pinxteren, D., Triesch, N., Hoffmann, E. H., Cree, C. H. L., Fitzsimons, M. F., von Tümpling, W., and Herrmann, H.: Aliphatic amines at the Cape Verde Atmospheric Observatory: Abundance, origins and sea-air fluxes, Atmos. Environ., 203, 183-195, https://doi.org/10.1016/j.atmosenv.2019.02.011, 2019.

van Pinxteren, M., Fomba, K. W., Triesch, N., Stolle, C., Wurl, O., Bahlmann, E., Gong, X., Voigtländer, J., Wex, H., Robinson, T.-B., Barthel, S., Zeppenfeld, S., Hoffmann, E. H., Roveretto, M., Li, C., Grosselin, B., Daële, V., Senf, F., van Pinxteren, D., Manzi, M., Zabalegui, N., Frka, S., Gašparović, B., Pereira, R., Li, T., Wen, L., Li, J., Zhu, C., Chen, H., Chen, J., Fiedler, B., 
von Tümpling, W., Read, K. A., Punjabi, S., Lewis, A. C., Hopkins, J. R., Carpenter, L. J., Peeken, I., Rixen, T., Schulz-Bull, D., Monge, M. E., Mellouki, A., George, C., Stratmann, F., and Herrmann, H.: Marine organic matter in the remote environment of the Cape Verde islands - an introduction and overview to the MarParCloud campaign, Atmos. Chem. Phys., 20, 6921-6951, https://doi.org/10.5194/acp-20-6921-2020, 2020.

Wang, X., Deane, G. B., Moore, K. A., Ryder, O. S., Stokes, M. D., Beall, C. M., Collins, D. B., Santander, M. V., Burrows, S. M., Sultana, C. M., and Prather, K. A.: The role of jet and film drops in controlling the mixing state of submicron sea spray aerosol particles, P. Natl. Acad. Sci., 114, 6978-6983, https://doi.org/10.1073/pnas.1702420114, 2017.

Wedyan, M. A. and Preston, M. R.: The coupling of surface seawater organic nitrogen and the marine aerosol as inferred from enantiomer-specific amino acid analysis, Atmos. Environ., 42, 8698-8705, https://doi.org/10.1016/j.atmosenv.2008.04.038, 2008.
Wilson, T. W., Ladino, L. A., Alpert, P. A., Breckels, M. N., Brooks, I. M., Browse, J., Burrows, S. M., Carslaw, K. S., Huffman, J. A., Judd, C., Kilthau, W. P., Mason, R. H., McFiggans, G., Miller, L. A., Najera, J. J., Polishchuk, E., Rae, S., Schiller, C. L., Si, M., Temprado, J. V., Whale, T. F., Wong, J. P. S., Wurl, O., Yakobi-Hancock, J. D., Abbatt, J. P. D., Aller, J. Y., Bertram, A. K., Knopf, D. A., and Murray, B. J.: A marine biogenic source of atmospheric ice-nucleating particles, Nature, 525, 234-238, https://doi.org/10.1038/nature14986, 2015.

Wolber, P. and Warren, G.: Bacterialice-nucleation proteins, Trends Biochem. Sci., 14, 179-182, https://doi.org/10.1016/09680004(89)90270-3, 1989.

Wurl, O., Ekau, W., Landing, W. M., and Zappa, C. J.: Sea surface microlayer in a changing ocean - A perspective, Elementa-Sci. Anthrop., 5, 11, https://doi.org/10.1525/elementa.228, 2017.

Zhang, Q. and Anastasio, C.: Free and combined amino compounds in atmospheric fine particles $\left(\mathrm{PM}_{2.5}\right)$ and fog waters from Northern California, Atmos. Environ., 37, 2247-2258, https://doi.org/10.1016/s1352-2310(03)00127-4, 2003. 